\title{
Radiative signature of absorbing aerosol over the eastern Mediterranean basin
}

\author{
A. K. Mishra ${ }^{1}$, K. Klingmueller ${ }^{2}$, E. Fredj ${ }^{1}$, J. Lelieveld ${ }^{3}$, Y. Rudich ${ }^{1}$, and I. Koren ${ }^{1}$ \\ ${ }^{1}$ Department of Earth and Planetary Sciences, Weizmann Institute of Science, Rehovot 76100, Israel \\ ${ }^{2}$ The Cyprus Institute, P.O. Box 27456, 1645 Nicosia, Cyprus \\ ${ }^{3}$ Max Planck Institute for Chemistry, P.O. Box 3060, 55020 Mainz, Germany \\ Correspondence to: Y. Rudich (yinon.rudich@weizmann.ac.il) and I. Koren (ilan.koren@weizmann.ac.il)
}

Received: 10 January 2014 - Published in Atmos. Chem. Phys. Discuss.: 24 January 2014

Revised: 7 May 2014 - Accepted: 28 May 2014 - Published: 16 July 2014

\begin{abstract}
The effects of absorbing aerosols on the atmospheric radiation budget and dynamics over the eastern Mediterranean region are studied using satellites and ground-based observations, and radiative transfer model calculations, under summer conditions. Climatology of aerosol optical depth (AOD), single scattering albedo (SSA) and size parameters were analyzed using multiyear (1999-2012) observations from Moderate Resolution Imaging Spectroradiometer (MODIS), Multi-angle Imaging SpectroRadiometer (MISR) and AErosol RObotic NETwork (AERONET). Cloud-Aerosol Lidar with Orthogonal Polarization (CALIOP)-derived aerosol vertical distributions and their classifications are used to calculate the AOD of four dominant aerosol types: dust, polluted dust, polluted continental, and marine aerosol over the region. The seasonal mean (June-August 2010) AODs are $0.22 \pm 0.02,0.11 \pm 0.04,0.10 \pm 0.04$ and $0.06 \pm 0.01$ for polluted dust, polluted continental, dust and marine aerosol, respectively. Changes in the atmospheric temperature profile as a function of absorbing aerosol loading were derived for the same period using observations from the AIRS satellite. We inferred heating rates in the aerosol layer of $\sim 1.7 \pm 0.8 \mathrm{~K} \mathrm{day}^{-1}$ between 925 and $850 \mathrm{hPa}$, which is attributed to aerosol absorption of incoming solar radiation. Radiative transfer model (RTM) calculations show significant atmospheric warming for dominant absorbing aerosol over the region. A maximum atmospheric forcing of $+16.7 \pm 7.9 \mathrm{Wm}^{-2}$ is calculated in the case of polluted dust, followed by dust $\left(+9.4 \pm 4.9 \mathrm{Wm}^{-2}\right)$ and polluted continental $\left(+6.4 \pm 4.5 \mathrm{Wm}^{-2}\right)$. RTM-derived heating rate profiles for dominant absorbing aerosol show warming
\end{abstract}

of $0.1-0.9 \mathrm{~K} \mathrm{day}^{-1}$ in the aerosol layer ( $<3.0 \mathrm{~km}$ altitudes), which primarily depend on AODs of the different aerosol types. Diabatic heating due to absorbing aerosol stabilizes the lower atmosphere, which could significantly reduce the atmospheric ventilation. These conditions can enhance the "pollution pool" over the eastern Mediterranean.

\section{Introduction}

Atmospheric aerosols constitute an important component of Earth's radiation balance and in determining cloud properties and consequences (Forster et al., 2007). The uncertainties related to the aerosol radiative forcing are large and have imposed a major challenge in understanding the anthropogenic role in climate change (Forster et al., 2007; Stevens and Feingold, 2009; Leibensperger et al., 2012). These large uncertainties are mainly associated with great spatial and temporal variability of aerosol composition and loading. Aerosols affect the radiation budget both directly through scattering and absorption of solar radiation and indirectly through modifying cloud microphysics (Kaufman et al., 2001; Kaufman and Koren, 2006; Khain, 2009; Li et al., 2011; Seiki and Nakajima, 2014). By absorbing solar radiation, aerosol can modify atmospheric stability and hence affect cloud formation and dissipation that could possibly impact precipitation (Ramanathan et al., 2005; Koren et al., 2008). Recent studies (Davidi et al., 2009, 2012; Wang, 2010) have shown that elevated biomass burning aerosol over the Amazon and dust particles (Saharan Aerosol Layer) over the Atlantic Ocean can lead to a temperature increase of that layer by $2-4 \mathrm{~K}$. 
These results call for more studies on the possible effects of absorbing aerosol over other climatically sensitive regions of the world.

The Mediterranean basin is a crossroad of different aerosol types (Lelieveld et al., 2002; Markowicz et al., 2002), which makes it an ideal natural laboratory to study the effect of different types of absorbing aerosol on the regional and local radiation budget and the consequences for atmosphere dynamics in the region. In general, this region is significantly impacted by variety of aerosol types including mineral dust from Africa and the Middle East, pollution from Europe and nearby coastal regions, and background marine aerosol (Moulin et al., 1998; Lelieveld et al., 2002; Gerasopoulos et al., 2006; Erel et al., 2006; Di Iorio et al., 2009). The seasonality of aerosol types over the basin (Vrekoussis et al., 2005; Pace et al., 2006; Marey et al., 2011) calls for investigation of the contribution of absorbing aerosols to total aerosol radiative forcing. Moreover, the absorption of incoming solar radiation by aerosols is greatly enhanced during the summer cloud-free conditions due to the intense solar radiation. Mallet et al. (2013) recently reported the dominance of absorbing aerosol over the eastern part as compared to the western part of the basin during the summer season, indicating that the absorbing nature of the aerosol is dominant during summer. Absorbing aerosols were shown to increase the absorption of solar radiation in the atmospheric column $\left(+11.1 \mathrm{Wm}^{-2}\right)$ and reduce the surface radiation $\left(-16.5 \mathrm{Wm}^{-2}\right)$ inducing significant atmospheric warming and surface cooling over the region (Papadimas et al., 2012).

Markowicz et al. (2002) found that the daily averaged atmospheric warming $\left(+11.3 \mathrm{Wm}^{-2}\right)$ and surface cooling $\left(-17.9 \mathrm{Wm}^{-2}\right)$ by summertime absorbing aerosol over the Mediterranean are similar to the highly absorbing south Asian haze observed over the Arabian Sea. Significant negative radiative forcing at the surface has also been reported in dust dominant $\left(-70.8 \mathrm{Wm}^{-2}\right)$ and pollution dominant $\left(-39.1 \mathrm{Wm}^{-2}\right)$ case studies (Meloni et al., 2003). Di Sarra et al. (2008) estimated that the average daily forcing (at the surface) at the summer solstice and equinox for desert dust is -30 and $-24 \mathrm{Wm}^{-2}$, respectively. Numerous other studies have also emphasized the significant role of absorbing aerosol over the Mediterranean region (Kazadzis et al., 2009; Santese et al., 2010; Di Biagio et al., 2010). Nevertheless, the inferences of these studies (atmospheric warming and surface cooling due to absorbing aerosol) are derived from the calculation of direct radiative forcing of aerosol using radiative transfer models mainly focused over the Mediterranean island of Lampedusa, Crete and some southern European countries. To the best of our knowledge there have been no direct measurement of absorbing aerosol's effect on the atmospheric temperature profile (i.e. change in atmospheric stability due to absorbing aerosol loading) over the region nor attribution of it to different aerosol types.

Given the importance of the strong atmospheric absorption in the eastern Mediterranean basin, we have conducted a comprehensive study in order to characterize the effects of atmospheric absorption of the different aerosol types on the atmospheric stability and the resulting climatic effects over the region. To that end, long-term climatology ( $\sim 10$ year $)$ of aerosol optical (extinction/absorption) and microphysical properties (size parameters) has been established for the eastern Mediterranean. The effect of absorbing aerosol on tropospheric atmospheric stability has been studied using the state of the art remote sensing methodology (satellite measure of aerosol loading and temperature profile). Finally, the observed properties of different aerosol types have been used in a radiative transfer model to estimate the resulting climate effects.

\section{Methodology}

Combined analyses of multiple data sets, derived from satellite, ground based measurements and radiative transfer model results, are used in this study. We focused on the eastern Mediterranean between 24.5 to $34.5^{\circ} \mathrm{E}$ and 32.5 to $35.5^{\circ} \mathrm{N}$. The rectangular box over the eastern Mediterranean basin in Fig. 1 represents the region of interest (ROI) for the present study. The analyzed ROI (area encompasses $\sim 5000 \mathrm{~km}^{2}$ ) has been chosen due to (1) focus on the eastern part of the basin which is significantly impacted by near and distant variable aerosol sources (Vrekoussis et al., 2005; Melin and Zibordi, 2005; Dermian et al., 2006; Basart et al., 2009) and (2) reliability of the satellite products over the marine regions (surface albedo effect). The flow chart of methodology is given in Fig. 2 which is explained as follows:

Monthly averaged (2002-2012) Moderate Resolution Imaging Spectroradiometer (MODIS; $1^{\circ} \times 1^{\circ}$ ) and Multiangle Imaging SpectroRadiometer (MISR; $0.5^{\circ} \times 0.5^{\circ}$ ) level 3 derived aerosol properties (Diner et al., 1998; Kahn et al., 2005; Levy et al., 2007; Remer et al., 2008) have been used to study the long-term climatology over ROI. We have also used $1^{\circ} \times 1^{\circ}$ gridded MODIS-derived daily averaged aerosol optical depth (AOD at $550 \mathrm{~nm}$ ) and fine fraction (ff) along with the Atmospheric Infra-Red Sounder (AIRS)-derived temperature $\left(1^{\circ} \times 1^{\circ}\right.$ spatial resolution) at four pressure levels: 1000, 925, 850 and $700 \mathrm{hPa}$ (Aumann et al., 2003; Diao et al., 2013) to analyze the absorption effect of aerosol on atmospheric stability. More details on accuracy and validation of AIRS temperature product can be found elsewhere (Davidi et al., 2009, and references therein). The AIRS temperature data are sorted according to AOD and divided into equally spaced bins of AOD. Both MODIS and AIRS fly on the Aqua platform $(\sim 01: 30$ p.m. LT), whereas MISR is on board Terra platform $(\sim 10: 30$ a.m. LT).

Twenty-four Aerosol Robotic Network (AERONET) sites have been chosen to represent the long-term (1999-2012) climatology of aerosol absorption and the size properties of the dominant aerosol types over the basin. We have used level 2 data of the single scattering albedo (SSA), AOD and 


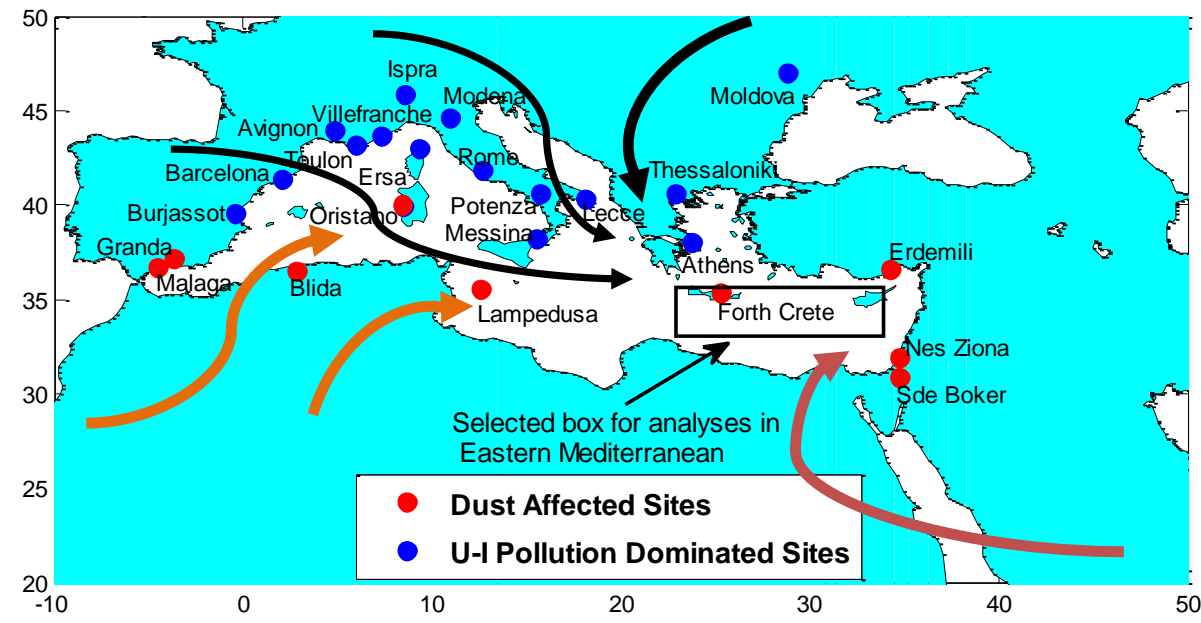

Figure 1. Classification of AERONET sites based on dominant aerosol types, which are likely to affect aerosol properties over the Mediterranean region. Red circles are used for dust affected sites and blue circles are used for urban-industrial (U-I) pollution dominated sites. Sites were selected based on data volume, geographic location, and primary aerosol source region. The rectangular box in the eastern Mediterranean presents our region of interest (ROI). The different color curved arrows show the schematic wind trajectories at different altitudes/time period during the summer season, 2010. The black arrows show transport of pollution from Europe, whereas light brown and dark brown show transport of dust particles from African and Arabian deserts, respectively.

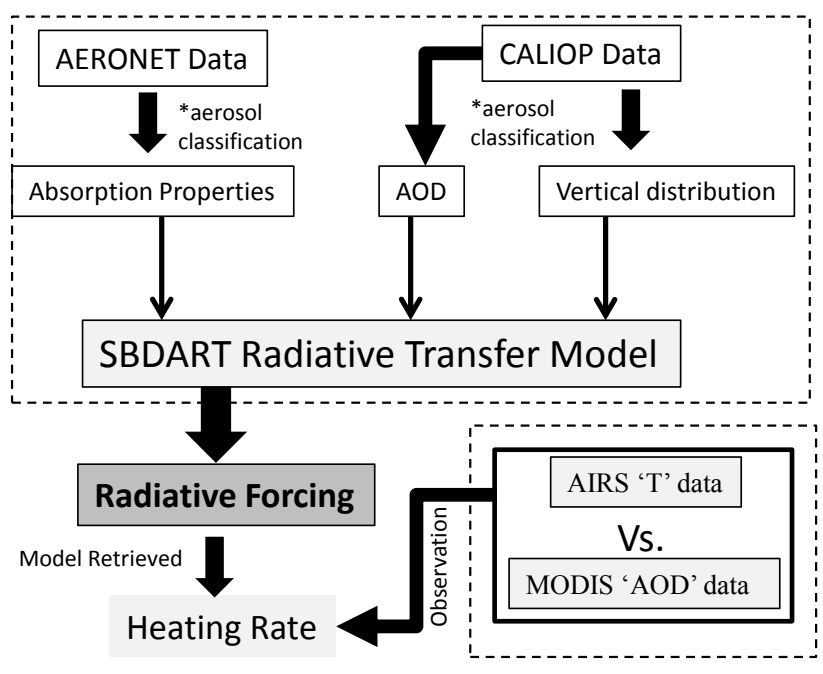

Figure 2. Flow chart of the methodology. The explanations are given in text. *Aerosol classification: aerosols are classified as dust, polluted dust (mixed aerosol), and polluted continental (pollution) classes. All optical and microphysical properties are derived for each class of aerosols.

asymmetry parameter (ASYM) at four wavelengths (440, 675, 870 and $1020 \mathrm{~nm}$ ). Following Russell et al. (2010), aerosol absorption optical depth $(\mathrm{AAOD}=[1-\mathrm{SSA}] \cdot \mathrm{AOD})$ follows a relatively smooth decrease with wavelength $(\lambda)$ and can be approximated with power-law wavelength dependence (AAOD $\sim \lambda^{-\mathrm{AAE}}$ ). By convention, absorption Angstrom exponent (AAE) is the negative of the slope of the absorption on a log-log plot. In the same manner, the ex- tinction Angstrom exponent (EAE) is calculated by powerlaw wavelength approximation ( $\mathrm{AOD} \sim \lambda^{-\mathrm{EAE}}$ ), which is used as a size parameter of aerosol particles. The details of the AERONET products and associated error analyses can be found elsewhere (Holben et al., 1998; Eck et al., 1999, 2013; Dubovik et al., 2000; Sinyuk et al., 2012). The selection of AERONET sites was based on extensive data volume (> 2.5 year) and geographical locations among aerosol source regions around the Mediterranean basin (Fig. 1). Each site is classified (following Mallet et al., 2013) as either dust affected or pollution dominated site based on the source regions and known seasonal changes in aerosol types over these regions (Holben et al., 2001; Tanre et al., 2001; Dubovik et al., 2002; Reid et al., 2003; Melin and Zibordi, 2005; Derimian et al., 2006; Eck et al., 2010; Giles et al., 2012; Mallet et al., 2013; Marconi et al., 2014). Dust affected sites are depicted by red circles and pollution dominated sites are shown by blue circles in Fig. 1. More details on site classification can be found in Mallet et al. (2013). Figure 3 plots averaged level $2 \mathrm{AOD}_{440}$ and $\mathrm{AAOD}_{440}$ with EAE $_{440-870}$ for all 24 sites. Red triangle represents the dust affected sites whereas blue circles show pollution dominated sites. Relatively higher AAOD and lower EAE of dust affected sites (except Forth Crete and Erdemli; see Table S1 in the Supplement) manifest the effect of dust particles in absorption and size parameters. We synthesize the optical models for the three different aerosol types (dust, polluted dust and polluted continental) over the Mediterranean. We have classified aerosol events based on daily AERONET observations. Our classification was done strictly based on the size parameter (EAE). For aerosol classification as dust, we used 

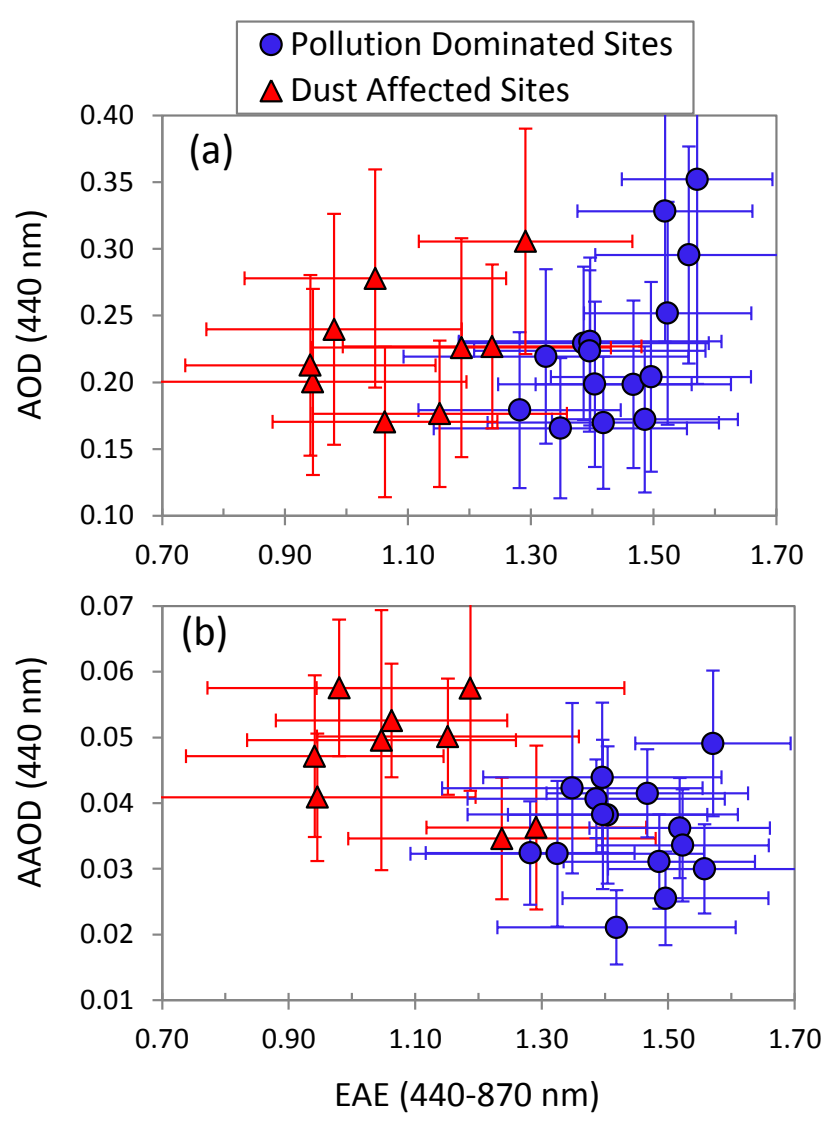

Figure 3. Average AERONET level 2 (entire data sets) scatter plots between (a) AOD vs. EAE and (b) AAOD vs. EAE for the 24 selected sites in and around the Mediterranean basin. The red triangles represent dust affected sites and blue circles show pollution dominated sites. The error bars represent $\pm \sigma / 2$, where $\sigma$ is standard deviation of AERONET level 2 (entire) data sets for respective sites.

all dust-dominated sites data with EAE <0.6. Dust model for individual sites can be seen in Fig. S1a in the Supplement. For classification as polluted dust (mixed aerosol) we included Athens and Messina (possible mixing sites) with all other dust dominated sites and selected AERONET data with $0.7<$ EAE $<1.1$. Pollution (polluted continental) has been characterized as EAE $>1.4$ for all pollution dominated sites. Polluted continental model for individual sites can be seen in Fig. S1b in the Supplement. The optical models for all three different absorbing aerosol types are presented for summer season (see Sect. 3.1). We treat DJF (December-JanuaryFebruary) as winter, MAM (March-April-May) as spring, JJA (June-July-August) as summer, and SON (SeptemberOctober-November) as autumn in this study.

In addition, we used the particle extinction coefficient ( $\sigma_{\text {ext }}$ at $532 \mathrm{~nm}$; L2_V3.01 product) profiles from the CloudAerosol Lidar with Orthogonal Polarization (CALIOP) onboard the Cloud-Aerosol Lidar and Infrared Pathfinder Satellite Observations (CALIPSO), to estimate the vertical pro- files of the different aerosol types (Winker et al., 2003; Young and Vaughan, 2009). The CALIOP aerosol identification algorithm (Omar et al., 2009) also provides details about the vertical profile of the different aerosol types. A total of 73 CALIPSO overpasses (37-day and 36-night time) over the ROI have been analyzed in this study. Although daytime profiles have relatively higher noise than nighttime profiles, both profiles have been used to maximize the number of observation in our study. To minimize possible artifacts due to cloud contamination in the extinction signals, a standard scheme (Winker et al., 2013; Fig. S2 in the Supplement) has been used to screen out all spurious points in our data sets (about $5 \%$ data was rejected). CALIOP-generated extinction profiles have been used in the calculation of AOD ( $\tau=\int_{z_{1}}^{z_{2}} \sigma_{\mathrm{ext}} \mathrm{d} z$ ) for various types of aerosol over the ROI.

We performed clear-sky solar irradiance, covers both short wavelength and long wavelength $(0.25-20 \mu \mathrm{m})$, computations using the Santa Barbara DISORT Atmospheric Radiative Transfer (SBDART) code (Ricchiazzi et al., 1998), which uses the discrete ordinates radiative transfer (DISORT) integration of the radiative transfer equations (Stamnes et al., 1988). This code includes multiple scattering in a vertically inhomogeneous, non-isothermal plane-parallel medium, and is computationally efficient in resolving the radiative transfer equation (McComiskey et al., 2008). The SBDART characterizes atmospheric aerosol radiative effects using as input the solar zenith angle $\left(0^{0}<\right.$ sza $<90^{0}$ with $5^{0}$ interval, and sza $=60^{\circ}$ is used for averaged daytime calculation), the spectral AOD, the spectral SSA, and the spectral ASYM.

To perform aerosol radiative forcing calculations in the $0.25-20 \mu \mathrm{m}$ wavelength range, aerosol properties in the entire wavelength region $(0.25-20 \mu \mathrm{m})$ are necessary. Since the measured AERONET aerosol optical properties are only available in the visible and near-infrared wavelength range $(\sim 0.4-1.0 \mu \mathrm{m})$, we used AERONET observed particle size distributions and refractive indices $(0.4-1.0 \mu \mathrm{m})$ to estimate the aerosol optical properties in the entire wavelength region $(0.25-20 \mu \mathrm{m})$. To extrapolate the refractive indices, we assume that the three aerosol types (dust, polluted dust and polluted continental) are internal mixtures of components with known short-wave and long-wave refractive indices. As mixing rule relating the refractive indices of mixture and components, we used the volume averaged refractive index mixing rule. The components assumed are as follows: mineral dust and water for dust-dominated aerosol; mineral dust, black carbon and water for polluted dust; ammonium sulphate, and black carbon and water for polluted continental aerosol. In the latter case, ammonium sulphate is representative for various components with similar refractive indices. The refractive indices of the components are taken from Hess et al. (1998) for black carbon and mineral dust (SW), Rothman et al. (2005) for ammonium sulphate and water and I. N. Sokolik (unpublished data, 2005) for mineral dust (LW). The volume fractions are chosen such that the refractive 
indices integrated over the wavelengths range of the observations (440-1020 nm) agree with the observed AERONET values. We obtain the following mean volume fractions: $79.6 \%$ mineral dust, $20.4 \%$ water (dust); $38.5 \%$ ammonium sulphate, $1.7 \%$ black carbon, $59.8 \%$ water (polluted continental); $60 \%$ mineral dust, $0.5 \%$ black carbon, $39.5 \%$ water (polluted dust). Using these volume fractions combined with the refractive indices of the components and the observed particle size distributions, we compute the aerosol optical properties. Scattnlay (Peña and Pal, 2009) Mie code is employed for calculations of optical properties (AOD, AAOD, SSA, ASYM). To obtain an error estimate, the standard deviation of the observations is propagated using jackknife resampling (Wu, 1986). The output AODs for each aerosol type is scaled with CALIOP-derived AOD.

The spectral SSA and the spectral ASYM are obtained from the abovementioned procedure for different dominant aerosol types, whereas the vertical distributions of aerosol types and AOD are supplied from CALIOP measurements. The atmospheric model (McClatchey et al., 1972; Ricchiazzi et al., 1998) input was set as "Mid-Latitude Summer Atmosphere". SBDART characterized "ocean water" surface type was used to parameterize the spectral albedo of surface (Tanré et al., 1990; Ricchiazzi et al., 1998). The instantaneous values of aerosol radiative forcing $\left(\Delta F_{\text {aer }}\right)$ have been derived as $\Delta F_{\text {aer }}=\left(F^{\downarrow}-F^{\uparrow}\right)-\left(F_{0}^{\downarrow}-F_{0}^{\uparrow}\right)$, where $F$ and $F_{0}$ denote the global irradiances with aerosol and without aerosol, respectively. The arrows indicate the direction of the global irradiances (down and up).

\section{Results and discussion}

\subsection{Aerosol climatology}

Figure 4 shows the 10 year (2002-2012) monthly averaged variation of MODIS- and MISR-derived aerosol optical depth and MODIS-derived cloud fraction (CF) over the ROI. Both instruments show similar trend of aerosol loading with some discrepancies in the averaged values. Possible explanations for these discrepancies in AOD are (1) the instruments' footpaths cover different areas; (2) the overpass time of the two platforms is different; and (3) technical reasons such as different retrieval algorithms (Kahn et al., 2007), different processing methods (Abdou et al., 2005) and calibration. A detailed discussion about aerosol measurement differences between these two sensors can be found elsewhere (Kahn et al., 2007; Xiao et al., 2009; Shi et al., 2011). A significant seasonal variability in aerosol loading with maximum in spring (April) and minimum in winter (more exactly from November to January) is found over the ROI. The ten-year average seasonal mean AODs are 0.24-0.25, $0.20-0.23,0.17-0.19$ and $0.17-0.18$ in spring, summer, autumn and winter, respectively. This seasonal dependence is explained by the seasonal variability in the major sources of

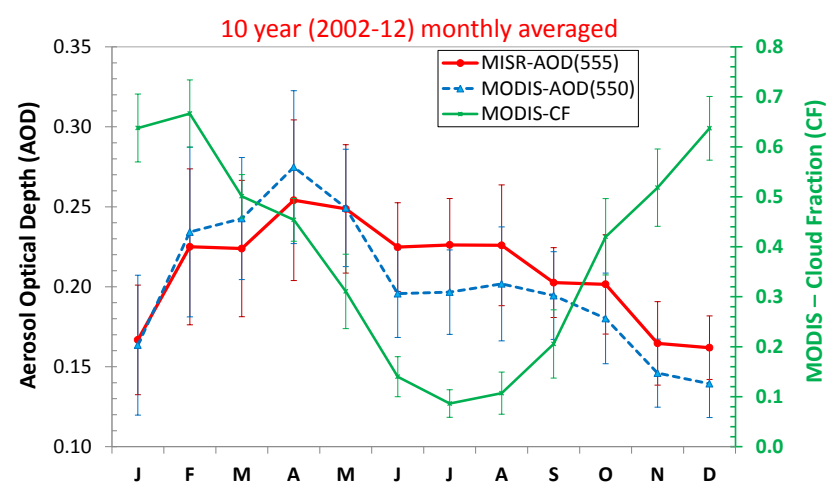

Figure 4. Seasonal variation of 10 year (2002-2012) monthly averaged aerosol optical depth (AOD) and cloud fraction (CF) over the ROI observed from MODIS and MISR. Error bars represent the standard deviation of inter-annual variability.

aerosol loading over the Mediterranean that is a function of synoptic meteorology (Lelieveld et al., 2002; Vrekoussis et al., 2005; Pace et al., 2006; Kallos et al., 2007). Among all seasons, the summertime eastern Mediterranean is characterized by a relatively minor cloud fraction $(<0.15)$ and small AOD variability at intra-seasonal scale (Fig. 4). Due to the cloud-free conditions, high radiation intensity and less variability in aerosol loading during the summer, we have chosen this season to study the climatic effects of absorbing aerosol over the ROI. The another reason for choosing only summer season is that there are much less AERONET level-2 absorption data during other seasons (Mallet et al., 2013). The seasonal (summer) mean of AOD over the ROI for 10 years (2003-2012) are given in Table 1. The summertime mean AODs vary between 0.19 and 0.25 in the span of 10 years. The maximum and minimum AOD have been observed in 2010 and 2012, respectively. The ten-year averaged (20032012) AOD is $0.21 \pm 0.02$ in summer season over the ROI.

The summertime AERONET-derived absorption and size properties for each site are presented in Table 2 . The average AAE values are in the ranges of 0.95-2.24 and 0.931.58 for dust affected and pollution dominated sites respectively. Relatively higher values of AAE (2.24) for Lampedusa as compared to other dust dominated sites could be understood as the island is in close proximity to North Africa and could be more affected by dust rather than pollution from Europe. However, the explanation of this high AAE value of Lampedusa needs more deep introspection. Relatively lower values of AAE and higher values of EAE of Erdemli, Sede Boker and Nes Ziona amidst other dust affected sites can be understood as these sites are more affected by pollution than dust during summer season (also manifested by larger $\mathrm{SSA}_{440}$ values). The size parameter (EAE) shows lower values (0.82-1.39) for dust-affected sites and larger values (1.21-1.63) for pollution dominant sites. These absorption and size properties are well within the range of earlier reported values of worldwide dominant aerosol types (Dubovik 
Table 1. MODIS-derived summertime mean AOD at $550 \mathrm{~nm}$ ( \pm standard deviation) within the aerosol layer over the ROI for 10 years (2003-2012).

\begin{tabular}{rrrrrrrrrrr}
\hline Year & 2003 & 2004 & 2005 & 2006 & 2007 & 2008 & 2009 & 2010 & 2011 & 2012 \\
\hline AOD & 0.20 & 0.20 & 0.20 & 0.24 & 0.23 & 0.24 & 0.19 & 0.25 & 0.21 & 0.19 \\
& \pm 0.06 & \pm 0.10 & \pm 0.07 & \pm 0.13 & \pm 0.09 & \pm 0.11 & \pm 0.05 & \pm 0.12 & \pm 0.06 & \pm 0.07 \\
\hline
\end{tabular}

et al., 2002; Giles et al., 2012). The pollution dominated sites show slightly higher values of SSA 440 in the range of $0.91-$ $0.95 \pm 0.04$ except Potenza. Recently, Mallet et al. (2013) have shown that the Mediterranean urban-industrial aerosol appears moderately absorbing $\left(\mathrm{SSA}_{440} \sim 0.94-0.95 \pm 0.04\right.$ ) in most cases except for Rome and Athens $\left(\mathrm{SSA}_{440} \sim 0.89\right.$ $0.90 \pm 0.04)$ where the aerosol appears to be more absorbing. The differences of optical properties in this study and Mallet et al. (2013) can be understood as Table 2 depicts the averaged properties for summer season only whereas Mallet et al. (2013) consider the entire data set. However, Table S1 in the Supplement well corroborates with the findings of Mallet et al. (2013). The role of dust in summer could be seen by comparing the summer means (Table 2) and overall means (Table S1 in the Supplement) of EAE for dust affected sites situated in western basin (Blida, Malaga, Granada etc.). Dust events during summer are likely to decrease the EAE values over these sites. However, the eastern basin sites are more influenced by pollution as seen from increased values of EAE in summer as compared to overall means.

As we can see from the Table 2 that the optical properties of different sites in two different categories shows great variability. We have characterized dust $(\mathrm{EAE}<0.6)$, polluted dust $(0.7<\mathrm{EAE}<1.1)$ and polluted continental $(\mathrm{EAE}>1.4)$ aerosol using the size parameter to separate these three classes as discussed in the methodology section. The possible reason for this variability can be understood since the Mediterranean basin is a cross-road of different aerosol types that mix in variable concentrations at different locations. Figure 5 presents the spectral variation of the summertime averaged SSA, AAOD, ASYM and volume size distribution of dominant absorbing aerosol types over the Mediterranean basin. All four properties show three different classes of aerosol optical model with possible variance. The standard deviation in SSA at different wavelengths shows relatively higher values for polluted dust and pollution aerosols. However, the spectral shapes of SSA manifest the differences in absorption properties of these three different aerosol classes which can be also seen in AAOD plot. The spectral shape of the SSA for different aerosol types shows similar variation as reported in Russell et al. (2010). As SSA is an intrinsic property of aerosol and does not depend on the loading, it is used to separate the absorbing effect of dust, polluted dust and pollution in radiative transfer scheme (Sect. 3.4). The optical properties for all three aerosol types in $0.25-20 \mu \mathrm{m}$ wavelength region (as discussed in methodology section) are given in Fig. S3 in the Supplement.

\subsection{Spatial and vertical distributions of aerosol during summer}

As summer 2010 shows all range of AOD (from low to high values), it has been chosen for the analyses over the eastern Mediterranean basin. The seasonal mean of MODIS-derived AOD is $0.25 \pm 0.12$ over the ROI during summer 2010. Figure 6 shows the intra-seasonal variability of spatial distribution over the Mediterranean basin during summer 2010 . In terms of AOD spatial variability, all three months show significantly different distribution of aerosol loading across the basin. In June, almost the entire basin shows significantly higher aerosol loading $(0.2-0.5)$ with a maximum in the southwest part of the basin, whereas in July and August, the maximum aerosol loading is concentrated in the eastern part of the basin. Over the eastern basin, June and August are associated with higher aerosol loading (AOD $>0.2$ ) as compared to July (AOD $<0.2$ ). The MODIS-retrieved fine fraction (ff) provides a good idea about the size of particles suspended in the atmosphere. Figure 7 shows the relative frequency of occurrence of $\mathrm{ff}$ in all three months of summer 2010. The frequency of occurrence of higher values $(>0.5)$ of $\mathrm{ff}$ increases as the months progressed from June to August, indicating the increase in fine mode particles as the summer progressed. This intra-seasonal spatial variability can be explained as different air masses that come from Africa, Europe or the Middle East significantly change the aerosol properties over the basin. In general, the central and eastern Mediterranean basin is impacted by frequent dust events from Africa during June that significantly decrease during the rest of the season (Lelieveld et al., 2002). Moulin et al. (1998) have nicely presented the dust seasonality over the Mediterranean basin (west, central and eastern). They have found higher dust-AOD in spring $(0.14 \pm 0.05)$ than that in summer $(0.10 \pm 0.04)$ for eastern basin, whereas central and western basin shows higher dust loading in summer $(0.18 \pm 0.06$ and $0.14 \pm 0.04$, respectively) than that in spring $(0.15 \pm 0.06$ and $0.10 \pm 0.04$, respectively) over the period 1983-1994.

Figure 8a shows the CALIOP-retrieved monthly average aerosol extinction distribution for June, July and August during summer 2010. There is maximum extinction near the surface $\left(0.12-0.15 \mathrm{~km}^{-1}\right)$ in all three months that decreases 
Table 2. Summertime averaged optical properties of (level 2) of Mediterranean AERONET sites used in this study. $N$ represents the number of level 2 observation days during summer season used in analyses. The subscripts of parameters name show wavelength in nm.

\begin{tabular}{|c|c|c|c|c|c|c|c|}
\hline Site Name & $N$ & $\mathrm{AAE}_{440-870}$ & $\mathrm{EAE}_{440-870}$ & $\mathrm{AOD}_{440}$ & $\mathrm{SSA}_{440}$ & $\mathrm{AAOD}_{440}$ & $\mathrm{ASYM}_{440}$ \\
\hline \multicolumn{8}{|c|}{ Pollution dominated sites } \\
\hline Athens & 306 & $1.26 \pm 0.33$ & $1.52 \pm 0.35$ & $0.26 \pm 0.11$ & $0.91 \pm 0.03$ & $0.04 \pm 0.01$ & $0.70 \pm 0.02$ \\
\hline Avignon & 670 & $1.33 \pm 0.49$ & $1.47 \pm 0.33$ & $0.21 \pm 0.13$ & $0.91 \pm 0.03$ & $0.04 \pm 0.01$ & $0.69 \pm 0.02$ \\
\hline Barcelona & 315 & $1.29 \pm 0.57$ & $1.34 \pm 0.34$ & $0.26 \pm 0.12$ & $0.91 \pm 0.04$ & $0.05 \pm 0.02$ & $0.70 \pm 0.02$ \\
\hline Burjassot & 349 & $1.37 \pm 0.45$ & $1.21 \pm 0.34$ & $0.25 \pm 0.11$ & $0.93 \pm 0.03$ & $0.03 \pm 0.02$ & $0.71 \pm 0.02$ \\
\hline Ersa & 232 & $1.43 \pm 0.58$ & $1.37 \pm 0.36$ & $0.19 \pm 0.10$ & $0.95 \pm 0.02$ & $0.02 \pm 0.01$ & $0.69 \pm 0.02$ \\
\hline Ispra & 462 & $1.33 \pm 0.28$ & $1.62 \pm 0.22$ & $0.41 \pm 0.32$ & $0.93 \pm 0.03$ & $0.04 \pm 0.02$ & $0.71 \pm 0.03$ \\
\hline Lecce & 661 & $1.58 \pm 0.48$ & $1.44 \pm 0.45$ & $0.26 \pm 0.13$ & $0.92 \pm 0.04$ & $0.04 \pm 0.02$ & $0.68 \pm 0.03$ \\
\hline Messina & 284 & $1.31 \pm 0.45$ & $1.30 \pm 0.49$ & $0.26 \pm 0.12$ & $0.94 \pm 0.03$ & $0.03 \pm 0.01$ & $0.70 \pm 0.03$ \\
\hline Modena & 240 & $1.35 \pm 0.29$ & $1.51 \pm 0.33$ & $0.35 \pm 0.19$ & $0.93 \pm 0.03$ & $0.03 \pm 0.01$ & $0.70 \pm 0.03$ \\
\hline Moldova & 541 & $1.22 \pm 0.23$ & $1.63 \pm 0.24$ & $0.29 \pm 0.16$ & $0.94 \pm 0.03$ & $0.03 \pm 0.02$ & $0.70 \pm 0.02$ \\
\hline Potenza & 183 & $1.23 \pm 0.79$ & $1.23 \pm 0.41$ & $0.20 \pm 0.11$ & $0.89 \pm 0.06$ & $0.05 \pm 0.03$ & $0.69 \pm 0.03$ \\
\hline Rome & 533 & $1.56 \pm 0.54$ & $1.36 \pm 0.39$ & $0.25 \pm 0.12$ & $0.92 \pm 0.03$ & $0.04 \pm 0.02$ & $0.69 \pm 0.03$ \\
\hline Thessaloniki & 385 & $1.27 \pm 0.28$ & $1.58 \pm 0.34$ & $0.35 \pm 0.16$ & $0.94 \pm 0.02$ & $0.03 \pm 0.01$ & $0.70 \pm 0.02$ \\
\hline Toulon & 365 & $1.34 \pm 0.43$ & $1.53 \pm 0.33$ & $0.20 \pm 0.11$ & $0.94 \pm 0.02$ & $0.03 \pm 0.01$ & $0.69 \pm 0.02$ \\
\hline Villefranche & 353 & $0.93 \pm 0.39$ & $1.55 \pm 0.34$ & $0.25 \pm 0.15$ & $0.95 \pm 0.02$ & $0.03 \pm 0.01$ & $0.70 \pm 0.02$ \\
\hline \multicolumn{8}{|c|}{ Dust affected sites } \\
\hline Blida & 332 & $2.02 \pm 0.39$ & $0.82 \pm 0.41$ & $0.32 \pm 0.17$ & $0.89 \pm 0.02$ & $0.06 \pm 0.02$ & $0.72 \pm 0.03$ \\
\hline Malaga & 302 & $1.55 \pm 0.45$ & $0.88 \pm 0.34$ & $0.23 \pm 0.13$ & $0.89 \pm 0.03$ & $0.05 \pm 0.02$ & $0.72 \pm 0.03$ \\
\hline Granada & 480 & $1.78 \pm 0.44$ & $0.95 \pm 0.39$ & $0.21 \pm 0.11$ & $0.90 \pm 0.02$ & $0.05 \pm 0.01$ & $0.70 \pm 0.03$ \\
\hline Forth Crete & 483 & $1.57 \pm 0.52$ & $1.39 \pm 0.42$ & $0.24 \pm 0.10$ & $0.94 \pm 0.03$ & $0.03 \pm 0.01$ & $0.70 \pm 0.02$ \\
\hline Lampedusa & 276 & $2.24 \pm 0.61$ & $1.01 \pm 0.56$ & $0.26 \pm 0.14$ & $0.91 \pm 0.03$ & $0.04 \pm 0.02$ & $0.71 \pm 0.03$ \\
\hline Erdemli & 536 & $0.95 \pm 0.31$ & $1.36 \pm 0.24$ & $0.37 \pm 0.16$ & $0.94 \pm 0.03$ & $0.03 \pm 0.02$ & $0.71 \pm 0.02$ \\
\hline Sde Boker & 1103 & $1.15 \pm 0.52$ & $1.07 \pm 0.33$ & $0.22 \pm 0.10$ & $0.92 \pm 0.02$ & $0.04 \pm 0.01$ & $0.72 \pm 0.02$ \\
\hline Nes Ziona & 432 & $1.02 \pm 0.41$ & $1.23 \pm 0.32$ & $0.30 \pm 0.14$ & $0.93 \pm 0.04$ & $0.04 \pm 0.02$ & $0.72 \pm 0.03$ \\
\hline Oristano & 232 & $1.52 \pm 0.63$ & $1.17 \pm 0.50$ & $0.28 \pm 0.17$ & $0.89 \pm 0.02$ & $0.06 \pm 0.02$ & $0.71 \pm 0.03$ \\
\hline
\end{tabular}

significantly above $1 \mathrm{~km}$ altitudes. June and August show elevated (up to 2-5 km) aerosol supporting the earlier observation from MODIS measurements (long-range transport of dust from the African and the Arabian regions). CALIOPderived AOD also corroborated the MODIS observations i.e. significantly higher AOD in August $(0.25 \pm 0.12)$ and June $(0.19 \pm 0.09)$ as compared to July $(0.16 \pm 0.10)$. Recently Ma et al. (2013) reported that CALIPSO AOD is significantly lower than that of MODIS AOD over the major dust source regions (Sahara, Gobi etc.) of the world. However, the difference between these CALIOP- and MODIS-derived AODs is minimal $(\sim 0.05-0.07)$ over the Mediterranean basin during the summer season, which is also reflected in the present study. Oo and Holz (2011) demonstrated underestimation of AOD in oceanic regions in which CALIOP identifies clean marine, but the fine mode fraction from the MODIS suggests a mixture of fine and coarse aerosols. Several attempts have been made to compare the CALIOP aerosol classification with AERONET and airborne High Spectral Resolution Lidar (HSRL-1) (Mielonen et al., 2009; Burton et al., 2013). While mentioning the good agreement in $63-80 \%$ of the cases between the most common aerosol types, these studies have warned against uncritical use of CALIOP classifica- tion in scientific studies. Before using the CALIOP aerosol classification in our study, we performed a cross check using MODIS ff over the ROI. Figure 9 shows the assessment of MODIS ff for three different scenarios of dominant aerosol loading (dust, polluted dust and polluted continental) over the ROI. The mean values of ff are $0.44 \pm 0.11$, $0.55 \pm 0.12$ and $0.64 \pm 0.17$ for the dust, polluted dust and polluted continental dominant aerosol classes, respectively. Earlier studies have reported MODIS ff in the range of 0.250.45 for marine aerosols, $0.37-0.51$ for dust, and $0.83-0.92$ for anthropogenic aerosols over the various oceanic regions of the world (Kaufman et al., 2005; Yu et al., 2009; Jones and Christopher, 2007, 2011). Relatively lower values of ff are found in our cases (as compared to above-mentioned studies). These could be understood as marine aerosols are present in all three cases in our study (Fig. 9, black circles), which would likely decrease the average ff values for all three cases. Therefore, distribution of ff as compared to other above-mentioned studies is in close agreement with the aerosol classification for this present study.

The average vertical distributions of dominant aerosol types over the eastern Mediterranean are presented in Fig. 8b (standard deviations are presented in Fig. S4 in 

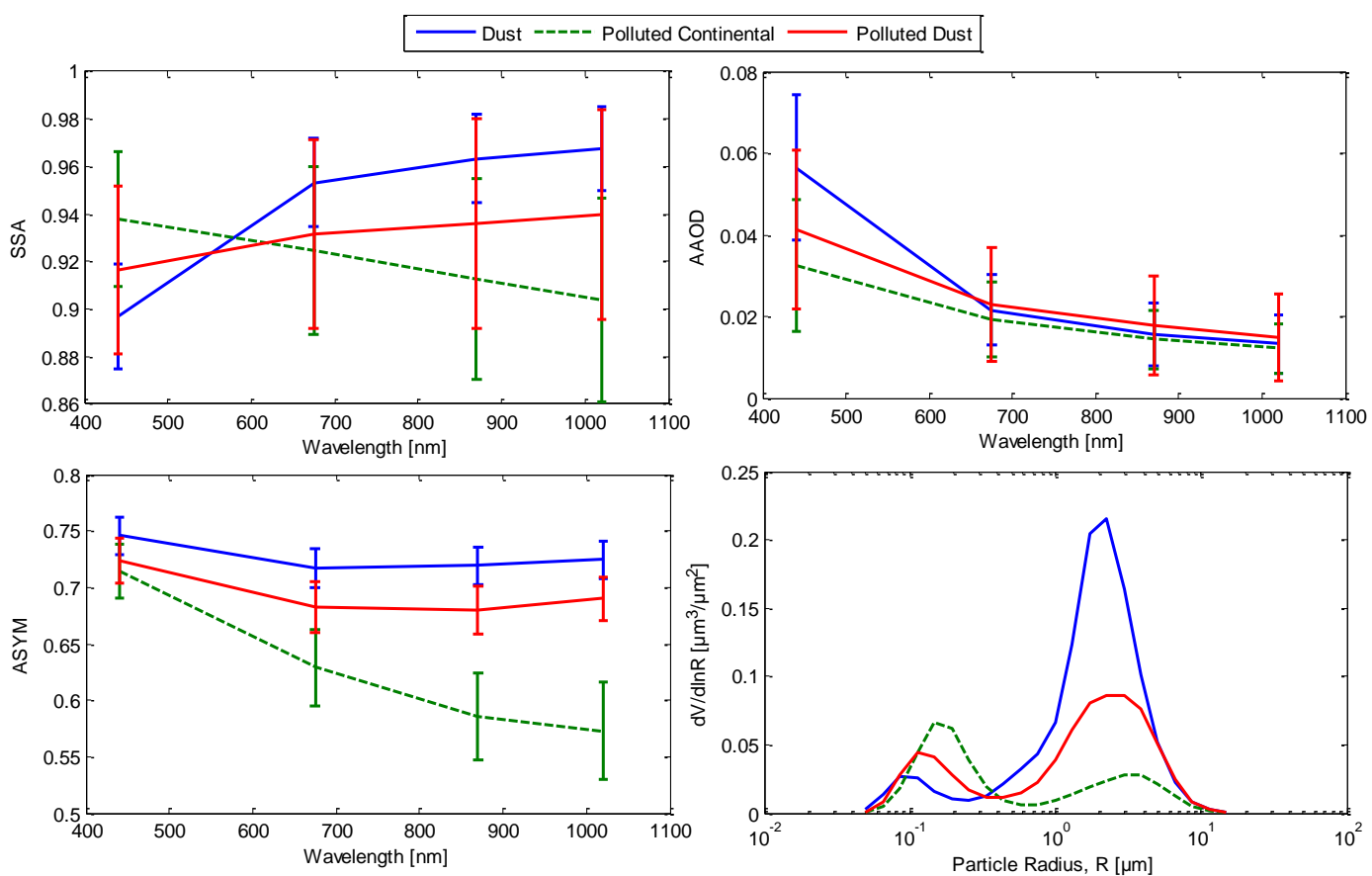

Figure 5. Spectral dependence of multi-year/multi-site average single scattering albedo (SSA), absorption aerosol optical depth (AAOD), asymmetry parameter (ASYM) and volume size distribution for dust, polluted dust and polluted continental over the Mediterranean basin. Total 259, 169 and 914 level 2 absorption data have been used to average for dust, polluted dust and polluted continental classes, respectively.
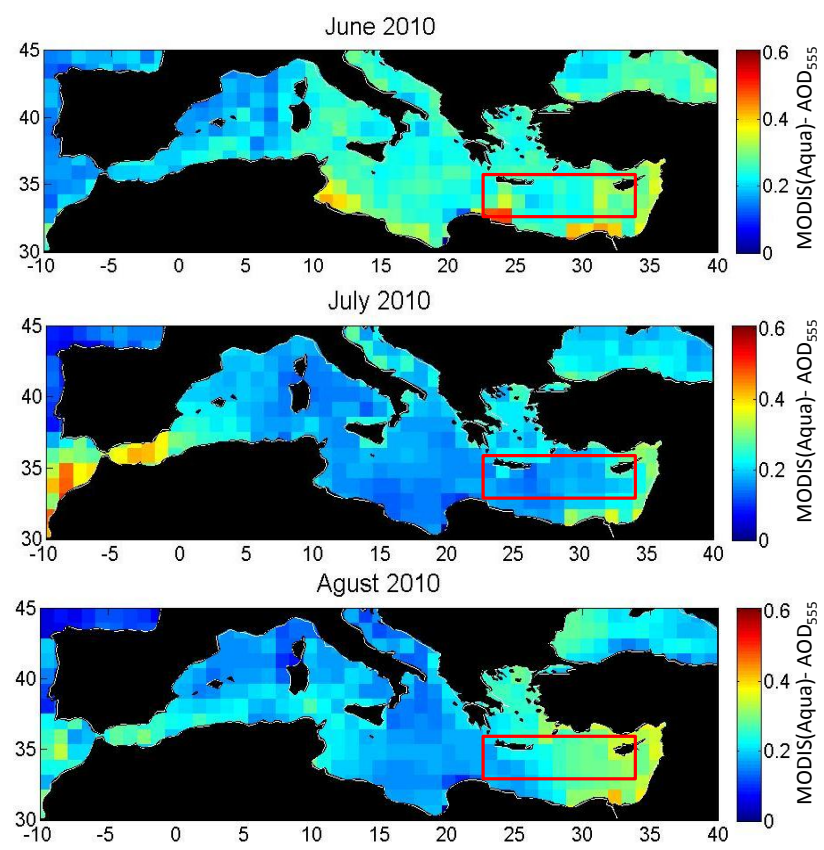

Figure 6. Monthly mean AOD during June-August 2010 over the Mediterranean basin. Red rectangular boxes present the ROI. the Supplement). Dust and polluted dust aerosol are frequently found at higher $(3-6 \mathrm{~km})$ altitudes, whereas polluted continental and marine aerosol are located within boundary layer (below $1.0-2.0 \mathrm{~km}$ altitudes). The maximal extinction has been shown by mixed aerosol (polluted dust $\sim 0.05-0.25 \mathrm{~km}^{-1}$ ) followed by pollution (polluted continental $\sim 0.02-0.15 \mathrm{~km}^{-1}$ ) in the lower troposphere (below $2.0 \mathrm{~km}$ altitude). The vertical distributions of different aerosol types from this study are well corroborated with Nabat et al. (2013), which have nicely presented a 4-dimensional climatology of aerosol properties over the Mediterranean basin. The seasonal mean (2010 summer) AOD of different dominant aerosol types are $0.22 \pm 0.02$, $0.11 \pm 0.04,0.10 \pm 0.04$ and $0.06 \pm 0.01$ for polluted dust, polluted continental, dust and marine aerosol, respectively. The higher contribution from polluted dust (mixed pollution + dust) reflects the real scenario over the Mediterranean, where the probability of mixing of anthropogenic pollution and natural dust is found to reach a maximum during the summer season.

\subsection{The effect of absorption on the atmospheric temperature profile}

Figure 10a shows the binned scatter plot of MODIS-AOD vs. AIRS-Temperature of four different pressure levels (1000, 925,850 and $700 \mathrm{hPa}$ ) for the summer 2010 . The seasonal mean altitudes representing the different pressure levels 

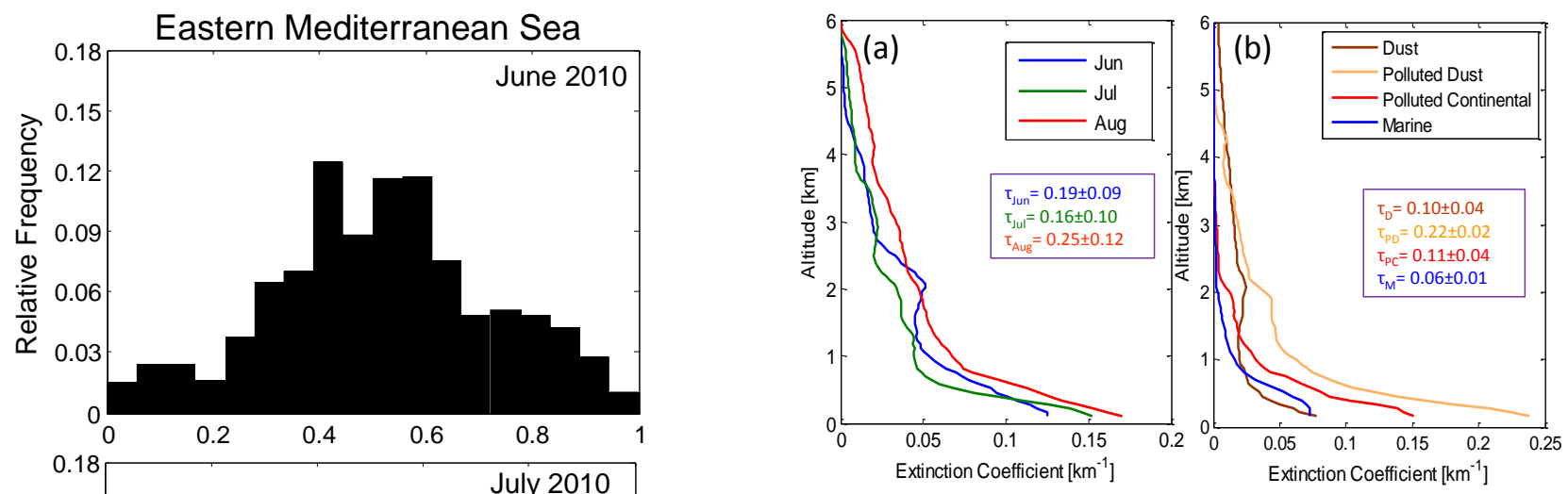

Figure 8. Vertical distribution of mean aerosol extinction coefficient for (a) June, July and August, and (b) different dominant aerosols during summer 2010. The calculated aerosol optical depths for respective extinction profiles are given in respective colors. The standard deviations of respective means are provided in supplementary materials (Fig. S4 in the Supplement).

row in Fig. 10a) in clean conditions (AOD 0.08) between 1000 and $850 \mathrm{hPa}$ is significantly lower than the standard adiabatic lapse rate $\left(\sim 14{ }^{\circ} \mathrm{C}\right.$ for $\left.1400 \mathrm{~m}\right)$. This indicates the stable atmosphere over the eastern Mediterranean. This average temperature difference decreases twofold $\left(\sim 4^{\circ} \mathrm{C}\right.$, dotted black arrow in Fig. 10a) in the case of high aerosol loading ( $\mathrm{AOD} \sim 0.58$ ), indicating that the diabatic heating in the presence of absorbing aerosol substantially increased the already existing stability of the lower troposphere. However, this role of absorbing aerosol is counteracted in the upper levels (between 850-700 hPa), where it adds instability to the already stable atmosphere (solid and dotted pink arrow in Fig. 10a). Fig. 10a shows that the difference between the temperatures at 850 and $925 \mathrm{hPa}$ is independent of aerosol loading, i.e. it is almost constant in the entire range of AOD (0.07 to 0.58). This observation suggests that the contribution of absorption from these two aerosol layers (at 850 and $925 \mathrm{hPa}$ ) is almost similar in magnitude. Figure S5 in the Supplement strengthened our abovementioned conclusion that the maximum observation due to absorbing aerosols (dust, polluted dust and polluted continental) occurs between $\sim 400$ and $\sim 2200 \mathrm{~m}$ altitude range with almost similar relative frequency of occurrence. A similar effect of absorbing aerosol has been reported by Davidi et al. $(2009,2012)$, where they have found an increase of $\sim 4^{\circ} \mathrm{C}$ at $850 \mathrm{hPa}$ in the case of smoke loading over the Amazon and $\sim 5-6^{\circ} \mathrm{C}$ increase in case of dust loading over the Atlantic. Ramanathan et al. (2001) have reported seasonal (JFM, 1999) and vertical averaged ( $0-3 \mathrm{~km}$ altitude) heating rate of $\sim 0.3-0.6 \mathrm{~K} \mathrm{day}^{-1}$ due to anthropogenic carbonaceous aerosols over the northern Indian Ocean region. Mineral dust layers have also shown heating rate of about $0.5 \mathrm{~K} \mathrm{day}^{-1}$ over the Arabian Sea and the Sahara coasts (Zhu et al., 2007). sure of stability in lower troposphere (Davidi et al., 2009). The mean temperature difference of $\sim 8^{\circ} \mathrm{C}$ (solid black ar- 

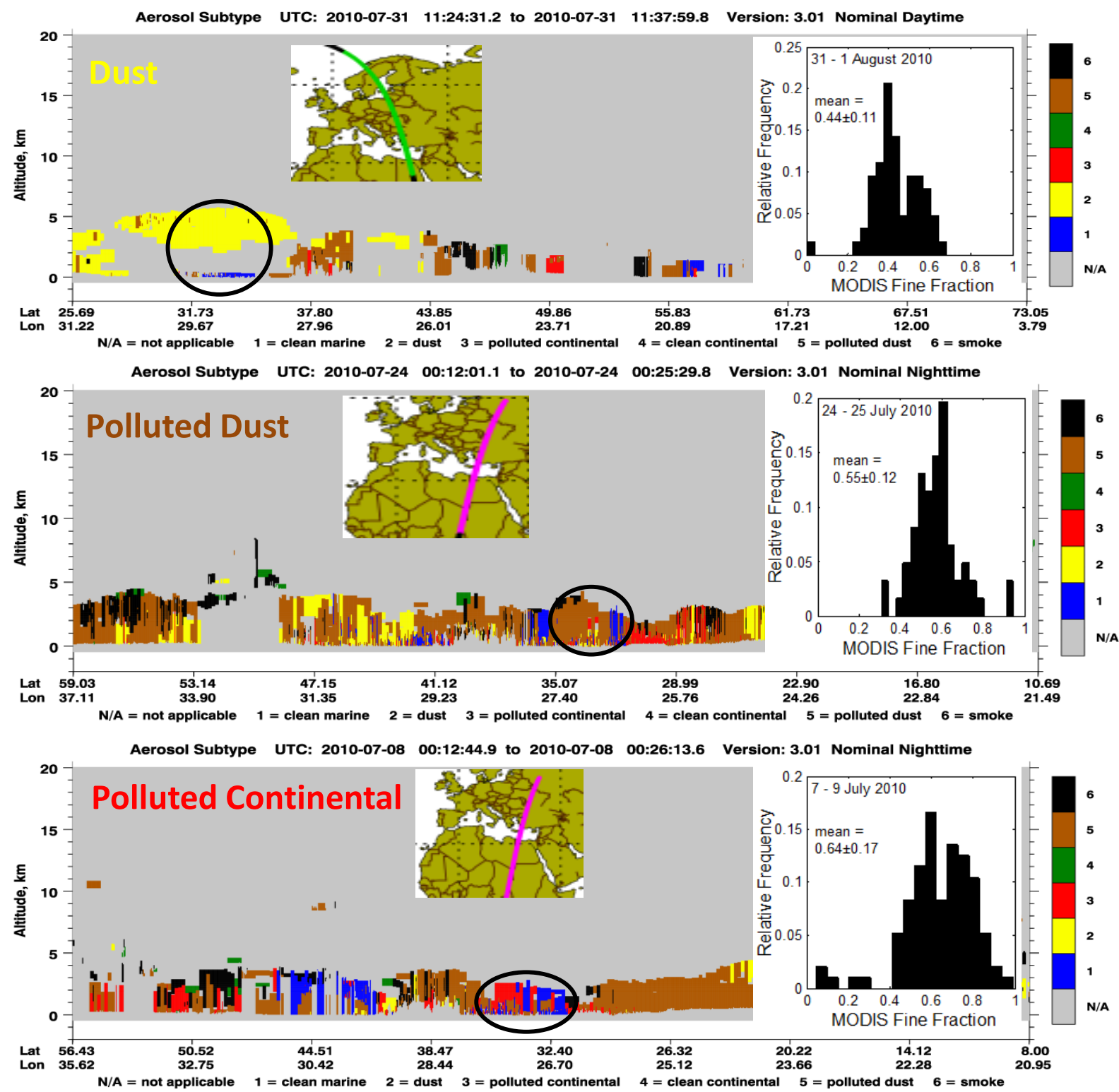

Figure 9. Assessment of CALIOP-derived aerosol classification (vertical feature mask: VFM) using MODIS fine fraction (ff) in three different cases of dust, polluted dust and polluted continental over the ROI. The relative frequency histogram of ff for each case is calculated over the ROI. Approximated latitudinal extent of ROI is shown by black circles for each case in VFM figure. The various colors of VFM represent different dominant aerosol types which are marked as integer number (1-6) in respective plots. The connotations of integer numbers are given at the bottom of each plot. The marine aerosols (blue color) are present in all three cases.

While this correlation between AIRS temperature and MODIS AOD is substantial with theoretical background related to diabatic heating of absorbing aerosol, one can question the (1) AIRS artifact in temperature retrieval in case of dust (Maddy et al., 2012) and (2) meteorology-driven changes in temperature, especially in the case of dust outbreaks. Because of their large sizes (up to several micrometer), dust particles are able to strongly interact with IR radiation and thus can affect the temperature retrieval in the thermal spectrum (Pierangelo et al., 2004; DeSouza-Machado et al., 2006). In addition, dust outbreaks are associated with dry and warm air, so it could carry the "memory of warm air" and could affect the temperature profiles during transport. We present the relative frequency distribution of AOD occurrence (upper panel) and ff (lower panel) for all observed data in Fig. 10b. The maximal relative frequency of AOD and ff appears around 0.2 and $0.5-0.8$, respectively. The mean values of temperature for each bin (Fig. 10a) integrate the effect of both fine and coarse particles. To address these issues, we show similar analyses (same as Fig. 10a) for two 
(a)

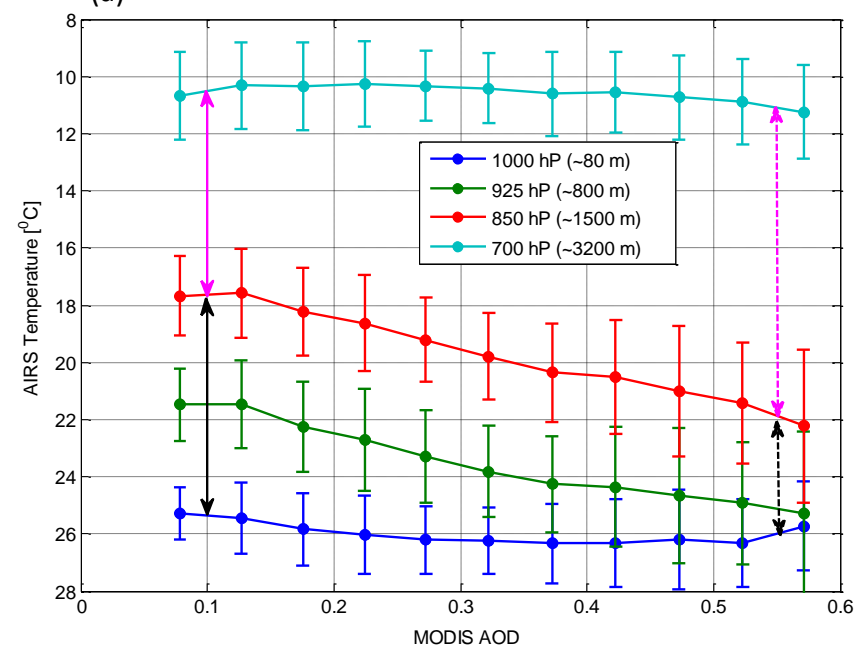

(b)
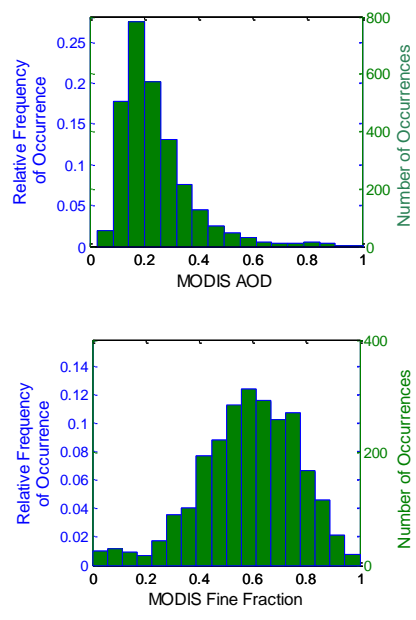

Figure 10. (a) MODIS AOD 550 vs. AIRS temperature at four different pressure levels $(1000,925,850$ and $700 \mathrm{hPa})$ for summer 2010 . The vertical axis is in reverse order. The bold and dotted black arrows represent temperature differences between 850 and $1000 \mathrm{hPa}$ levels (stability parameter) in cases of clean and hazy atmosphere, respectively. Similarly, the pink arrows show temperature differences between 700 and $850 \mathrm{hPa}$ levels. The AIRS temperature data are sorted according to AOD and divided into equal spaced bins of $0.05 \mathrm{AOD}_{550}$. Error bars present the standard deviation of points in each bin. (b) Relative frequency distribution of occurrence (blue bar lines are relative frequency and green are number of occurrence, both are scaled) of AOD (upper panel) and ff (lower panel) for all observed data over the ROI.

different cases of MODIS ff ( $\mathrm{ff}<0.5$ and $\mathrm{ff}>0.5$ ) in Fig. 11a. The number of sampled AOD pixels are comparably lower (around half) in case of $\mathrm{ff}<0.5$ than that of $\mathrm{ff}>0.5$ (Fig. 11b). The $\mathrm{ff}<0.5$ case associated with dust (left panel) shows a slightly cooler atmosphere (explanations are given below) than $\mathrm{ff}>0.5$ case (right panel) all along the profile, but the trend of $\mathrm{d}(T) / \mathrm{d}(\mathrm{AOD})$ is quite similar in both cases (fine and coarse) and also represents the essence of Fig. 10a. From this analysis, it is clear that the observed perturbation in temperature is apparent in both coarse (dust) and fine absorbing particles (pollution). These observations further strengthen the conclusion that the temperature increase is solely attributed to diabatic heating by absorbing particles.

The plausible reason of cooler atmosphere in case $\mathrm{ff}<0.5$ could be explained by Fig. S6 in the Supplement. Figure S6a in the Supplement shows that the AOD occurrence associated with large particles is maximal in June as compared to other two later months or in other words June month is highly impacted by dust events as compared to rest of season. Also the mean temperature climatology shows a gradual increase as days progressed from June to August. The daily mean values of AOD did not show any definite pattern with temperature except for a few events in June and August (marked as double headed arrow). All abovementioned analyses suggest that the coarse particles (dust events) dominant in early summer season which is also characterized by slightly lower atmospheric temperature. This could be a plausible reason of slightly lower atmospheric temperature in case of coarse particles $(\mathrm{ff}<0.5)$ than that in fine particle case $(\mathrm{ff}>0.5)$ in Fig. 11a.

\subsection{Atmospheric heating due to different aerosol types: model assessment}

The strong dependence of aerosol direct radiative forcing (ADRF) at top of the atmosphere (TOA) and at the surface (SRF) on solar zenith angle (SZA) has well observed by Boucher et al. (1998). In this study, the variation of radiative forcing of aerosol types (dust, polluted dust and polluted continental) with solar zenith angle (SZA) at TOA, at SRF and in the atmosphere (ATM) are given in Fig. S7 in the Supplement. Our results agree with those of Boucher et al. (1998). In spite of the strong variability of ADRF (at TOA and SRF) with SZA, we used sza $=60^{\circ}$ to show our results for daytime average (an approximation) because we compare our model assessment with the AIRS vs. MODIS analyses, which use instantaneous observations at 01:30 p.m. (LT) for each day. It is worth mentioning that using a single sza $=60^{\circ}$ (that is close to the maximum instantaneous DRE (Direct Radiative Effect)) overestimates the calculated DRE as compared to cosine of SZA weighted mean DRE at TOA and at SRF, but in the atmosphere (ATM) it will be slightly underestimated (Fig. S8 in the Supplement).

Figure 12 shows the clear-sky daytime averaged $\left(\mathrm{SZA}=60^{\circ}\right)$ aerosol radiative forcing $\left(\Delta F_{\mathrm{aer}}\right)$ of dominant aerosol types (dust, polluted dust, polluted continental and marine) at the surface (SRF), at the top of the atmosphere (TOA) and in the atmosphere (ATM) during summer 2010 over the eastern Mediterranean. The atmospheric forcing of aerosol is the difference between forcing at TOA and SRF $\left[\left(\Delta F_{\mathrm{aer}}\right)_{\mathrm{ATM}}=\left(\Delta F_{\mathrm{aer}}\right)_{\mathrm{TOA}}-\left(\Delta F_{\mathrm{aer}}\right)_{\mathrm{SRF}}\right]$. The 

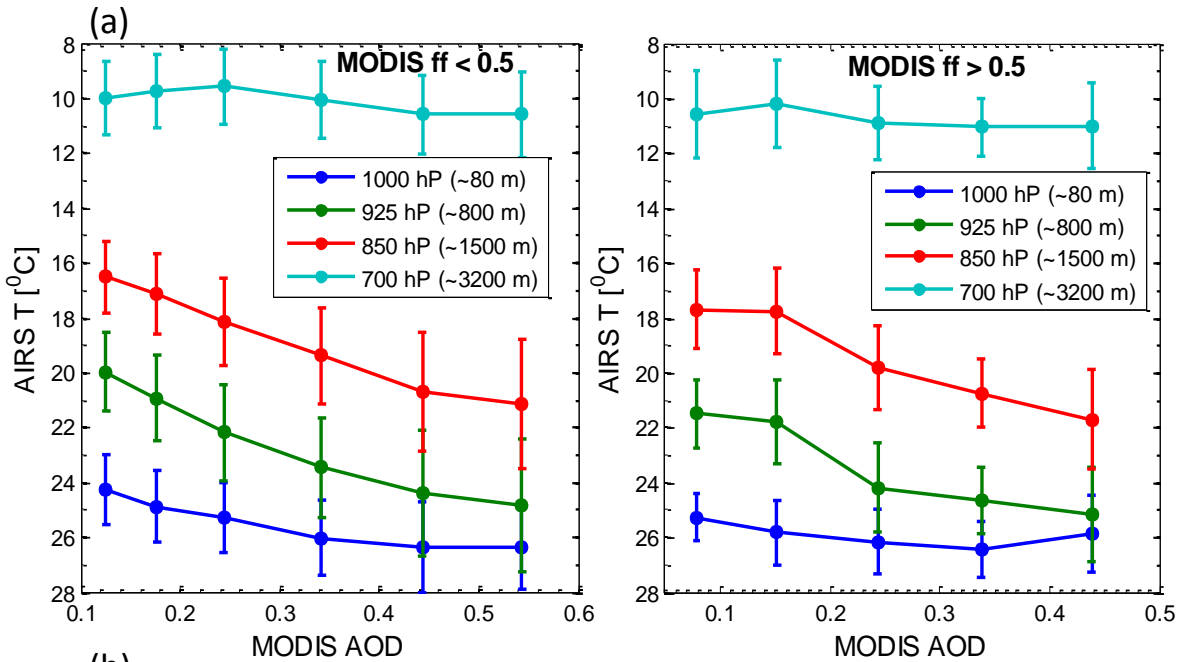

(b)
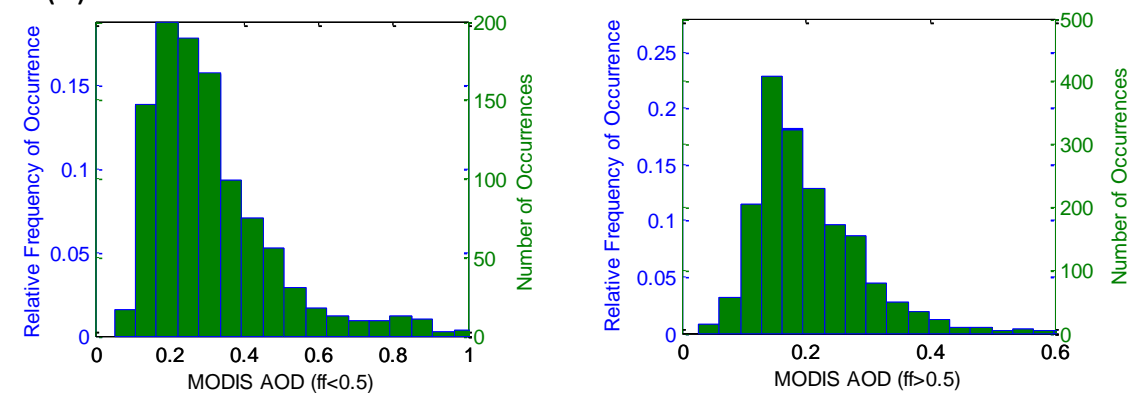

Figure 11. Same as (a) Fig. 10a and (b) Fig. 10b (upper panel) but separated in two cases of MODIS ff < 0.5 (left panel) and MODIS ff $>0.5$ (right panel). The horizontal axis of Fig. 11a are different for two cases ( $\mathrm{ff}<0.5$ and $\mathrm{ff}>0.5$ ) as AOD binning is done according to availability of data sets.

error bars show the total uncertainties in radiative forcing due to the uncertainty in the input parameters. We examined the dependence of forcing on each property, AOD, SSA and $g$ (sensitivity analyses of forcing to various parameters) separately (Fig. S9 in the Supplement). The sensitivity analyses have shown that the aerosol forcing values strongly depends on the AOD values as compared to any other properties (SSA and $g$ ). The total uncertainty in forcing, owing to the combined influence of the uncertainties in the various properties is determined under the assumption that these uncertainties are not correlated (McComiskey et al., 2008).

All dominant aerosol types show negative radiative forcing at both the surface and the TOA. The higher values of $\left|\left(\Delta F_{\text {aer }}\right)_{\mathrm{SRF}}\right|$ than that of $\left|\left(\Delta F_{\text {aer }}\right)_{\mathrm{TOA}}\right|$ are a result of the positive atmospheric forcing for almost all aerosol types, which reflect the absorbing behavior of these aerosols. However, this value $\left(\left(\Delta F_{\text {aer }}\right)_{\mathrm{ATM}}\right)$ is close to zero in the case of marine aerosol. The forcing values at TOA and at the surface are largest for polluted dust due to the high value of AOD. The maximal atmospheric forcing is observed in the case of polluted dust $\left(16.7 \pm 7.9 \mathrm{Wm}^{-2}\right)$ followed by dust $\left(9.4 \pm 4.9 \mathrm{Wm}^{-2}\right)$ and polluted continental

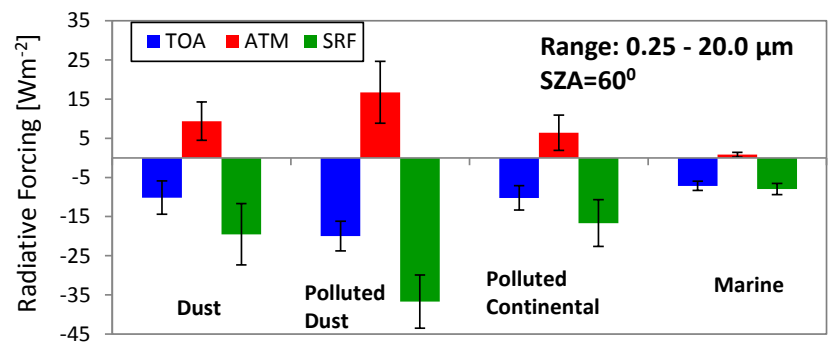

Figure 12. Day time average radiative forcing at top of the atmosphere (TOA), at surface (SRF) and in the atmosphere (ATM) for various dominant aerosol types over eastern Mediterranean during summer 2010. The error bars present the error in calculation of radiative forcing associated with errors in major input parameters (AOD, SSA and ASYM).

$\left(6.4 \pm 4.5 \mathrm{Wm}^{-2}\right)$ aerosol. The atmospheric radiative forcing efficiencies (defined by radiative forcing for unit optical depth) are found to be slightly more in case of dust $\left(+86.2 \mathrm{Wm}^{-2}\right)$ than polluted dust $\left(+77.2 \mathrm{Wm}^{-2}\right)$ and polluted continental $\left(+62.5 \mathrm{Wm}^{-2}\right)$. The significant positive radiative forcing for dominant absorbing aerosol corroborated our earlier observations of heating in the atmosphere 
(Sect. 3.3). Di Biagio et al. (2010) showed that these atmospheric forcing (at the summer solstice) could be increased up to $+35 \mathrm{Wm}^{-2}$ for desert dust (DD), $+23 \mathrm{Wm}^{-2}$ for pollution (UI (Urban Industrial)-BB (Biomass Burning)) and $+34 \mathrm{Wm}^{-2}$ for mixed aerosol (MA) in the highest aerosol loading for these classes (AOD $\sim 0.88$ for DD, 0.44 for UI-BB, and 0.45 for MA) over the Mediterranean region. The regional mean values of aerosol forcing over the broader Mediterranean basin under clear sky conditions have been found to be $+7.4 \pm 3.3,+19.2 \pm 2.9,+20.1 \pm 1.1$ and $+7.7 \pm 4.0 \mathrm{Wm}^{-2}$ for winter, spring, summer and autumn, respectively (Papadimas et al., 2012). The global mean atmospheric forcing (SW) of dust has been recently reported to be in the range of +1.57 to $+1.73 \mathrm{Wm}^{-2}$ using GEOSChem global three dimensional Chemical Transport Model coupled with Fu-Lion-Gu (FLG) radiative transfer model (Zhang et al., 2013). They also reported the FLG-derived radiative forcing over major dust prone regions of world: Sahara $\left(+15.22 \mathrm{Wm}^{-2}\right)$, Gobi $\left(+15.79 \mathrm{Wm}^{-2}\right)$, Arabian Sea $\left(+5.07 \mathrm{Wm}^{-2}\right)$ and eastern Asia $\left(+4.96 \mathrm{Wm}^{-2}\right)$.

Table 3 presents the daytime average aerosol radiative forcing in short wavelength (SW: $0.25-4.0 \mu \mathrm{m})$ and long

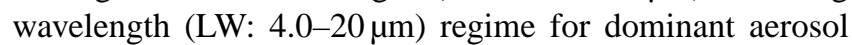
types. The LW radiative forcing is positive both at SRF and TOA since aerosol produced planetary and surface warming through interaction with infrared (IR) radiation. Figure S10 in the Supplement shows radiative forcing of different aerosols types as a function of wavelength for both SW and LW region. The importance of the particle size in the LW regime can be seen from the Fig. S10 in the Supplement and Table 3, where dust and polluted dust (diameter up to several micrometers) show higher forcing values as compared to polluted continental aerosol (diameter less than $1 \mu \mathrm{m}$ ). It is worth noting that we cannot expect significant radiative forcing of anthropogenic pollution in the LW region due to the small sizes of these particles. Bergamo et al. (2008) have reported that the IR surface direct radiative forcing of anthropogenic aerosol reach peak values close to $0.35 \mathrm{Wm}^{-2}$ (significantly larger than the TOA values) at most of the Mediterranean sites during summer and offset 3-6\% of the negative solar (SW) radiative forcing. Our results suggest that the role of absorbing aerosol are mainly associated with the SW region, where it absorbs and scatters the incoming SW solar radiation and thus produces the planetary and surface cooling effect. However, LW radiative forcing at SRF offset about 11.3 and $8.6 \%$ of the negative solar (SW) radiative forcing in case of dust and polluted dust, respectively.

Our results along with other earlier studies show significant atmospheric heating due to different absorbing aerosol types over the Mediterranean basin. Moreover the coupling of natural and anthropogenic pollution leads to higher heating in the atmosphere. It is interesting to investigate how much atmospheric heating (in terms of temperature change) and at which altitudes is contributed by absorbing aerosol. Figure 13 shows the atmospheric heating rate $\left(\mathrm{K} \mathrm{day}^{-1}\right)$ pro-

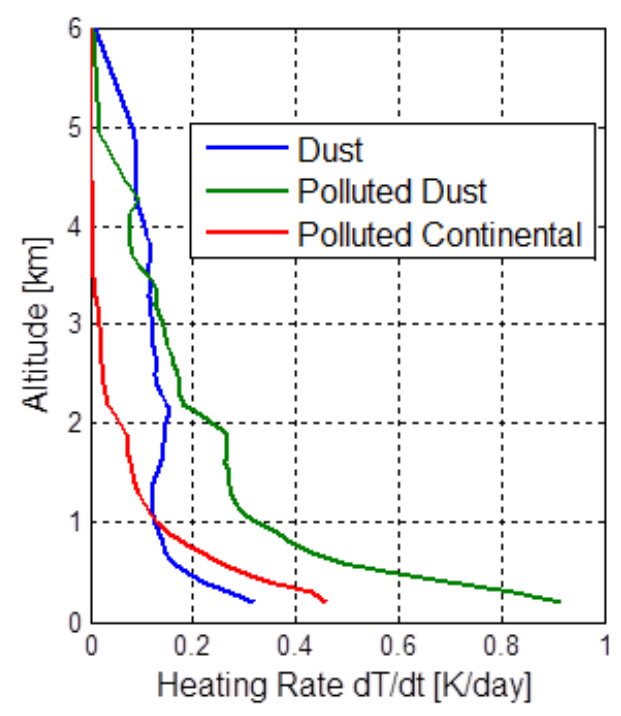

Figure 13. SBDART-derived heating rate profiles of dominant absorbing aerosol types (dust, polluted dust and polluted continental) over eastern Mediterranean basin during summer 2010.

files of dust, polluted dust and polluted continental over the eastern Mediterranean during summer 2010. Polluted dust shows the maximal heating rate $\left(0.2-0.9 \mathrm{~K} \mathrm{day}^{-1}\right)$ in the lower troposphere $(<2.0 \mathrm{~km}$ altitudes) followed by the polluted continental $\left(0.1-0.5 \mathrm{~K} \mathrm{day}^{-1}\right)$ aerosol. We also found a relatively small heating $\left(<0.1 \mathrm{Kday}^{-1}\right)$ at high altitudes $(>3.0 \mathrm{~km})$, in the case of both dust and polluted dust. The similarities in the shape of the vertical heating profiles (Fig. 13) and aerosol extinction profiles (Fig. 8b) suggest that the aerosol optical depth distribution plays a major role in the radiative forcing. Zhang et al. (2013) found that dust particles could heat the atmosphere by more than $0.5 \mathrm{~K} \mathrm{day}^{-1}$ over African and Asian source regions. Huang et al. (2009) have also shown that atmospheric heating of dust particles could reach up to $3 \mathrm{~K} \mathrm{day}^{-1}$ in heavy dust layers over the Taklimakan Desert in northwestern China.

\section{Implications on regional atmospheric dynamics}

By a good approximation, we can consider that the absorbing properties of aerosol are somewhat similar in all summer seasons and AOD is the main factor that affects the aerosol diabatic heating (on yearly basis) over the ROI. Retrieval of the effect of absorbing aerosol loading on atmospheric temperature profile reveals an increase of $\sim 4{ }^{\circ} \mathrm{C}$ due to aerosol during hazy ( $\mathrm{AOD} \sim 0.58$ ) conditions as compared to clean conditions. The average diabatic heating due to absorbing aerosol over the ROI was $\sim 1.7 \pm 0.8 \mathrm{Kday}^{-1}$ in summer 2010. The diabatic heating of absorbing aerosol is presented in Table 4 for ten years (2003-2012). SBDART calculations show significant diabatic heating $\left(0.1-0.9 \mathrm{~K} \mathrm{day}^{-1}\right)$ due to different absorbing aerosol in the lower troposphere. The 
Table 3. Daytime average aerosol radiative forcing $\left[\mathrm{Wm}^{-2}\right]$ in short wavelength $(\mathrm{SW})$ and long wavelength (LW) region for different absorbing aerosols during summer 2010 over the eastern Mediterranean basin.

\begin{tabular}{lcc|cc}
\hline Aerosol Type & \multicolumn{2}{c}{$\mathrm{SW}(0.25-4.0 \mu \mathrm{m})$} & \multicolumn{2}{c}{$\mathrm{LW}(4-20.0 \mu \mathrm{m})$} \\
\hline & $\left(\Delta F_{\mathrm{aer}}\right)_{\mathrm{SRF}}$ & $\left(\Delta F_{\mathrm{aer}}\right)_{\mathrm{TOA}}$ & $\left(\Delta F_{\mathrm{aer}}\right)_{\mathrm{SRF}}$ & $\left(\Delta F_{\mathrm{aer}}\right)_{\mathrm{TOA}}$ \\
\hline Dust & -21.95 & -11.05 & 2.47 & 0.91 \\
Polluted Dust & -39.95 & -20.60 & 3.31 & 0.64 \\
Polluted Continental & -17.41 & -10.27 & 0.78 & 0.07 \\
\hline
\end{tabular}

Table 4. Summertime observed approximated heating rate $[\mathrm{d} T / \mathrm{d} t \pm$ standard deviation] within the aerosol layer and MODIS-AOD ( \pm standard deviation) over the ROI in the eastern Mediterranean basin for 10 years (2003-2012).

\begin{tabular}{lrrrrrrrrrr}
\hline Year & 2003 & 2004 & 2005 & 2006 & 2007 & 2008 & 2009 & 2010 & 2011 & 2012 \\
\hline Heating & 1.4 & 1.4 & 1.4 & 1.7 & 1.6 & 1.7 & 1.3 & 1.7 & 1.5 & 1.3 \\
$\left(\right.$ K day $\left.^{-1}\right)$ & \pm 0.4 & \pm 0.7 & \pm 0.5 & \pm 0.9 & \pm 0.6 & \pm 0.8 & \pm 0.3 & \pm 0.8 & \pm 0.4 & \pm 0.4 \\
\hline AOD & 0.2 & 0.2 & 0.2 & 0.24 & 0.23 & 0.24 & 0.19 & 0.25 & 0.21 & 0.19 \\
& \pm 0.06 & \pm 0.10 & \pm 0.07 & \pm 0.13 & \pm 0.09 & \pm 0.11 & \pm 0.05 & \pm 0.12 & \pm 0.06 & \pm 0.07 \\
\hline
\end{tabular}

overestimated heating rate from AIRS vs. MODIS observation as compared to model calculations is attributed to the treatment of different aerosol types by the RTM, whereas the remote sensing calculation combined the effect of all aerosol types present. In addition, the different AOD used in both methods (CALIOP-derived in RTM and MODIS-derived in another one) could be an important reason for these differences. By now, it is evident that the absorbing aerosol is heating the atmospheric layers, so how is it going to affect or modulate the summertime regional dynamics over the eastern Mediterranean?

In general, the increase in temperature due to aerosol absorption stabilizes the lower atmosphere, leading to the weakening of convection in the lower atmosphere and may inhibit cloud formation (Ackerman et al., 2000). However, the summertime Mediterranean atmospheric condition is already too stable to form convective clouds over the region. The diabatic heating adds even more stability, which will significantly inhibit the atmospheric ventilation and could protect the aerosol from meteorological dilution. In other words, the absorbing aerosol loading over the significantly large area of the eastern Mediterranean Sea may create a low pressure in the lower atmosphere and may receive more pollution from nearby high pressure regions. Hence, the effect of absorption properties of the regional aerosols enhances the formation of a "pollution pool" over the region. Our results also suggest that the coupling between natural dust emissions and pollution leads to stronger heating. This suggests that a policy to reduce anthropogenic light absorbing pollution will have beneficial climatic impacts in the region. In a follow-up study, we will investigate the climate effects of these absorbing aerosols in more detail using the chemistry-climate coupled EMAC (ECHAM5/MESSy Atmospheric Chemistry) model.

\section{Conclusions}

A comprehensive study on the effects of absorbing aerosols on the regional atmospheric dynamics over the eastern Mediterranean basin (between 24.5 to $34.5^{\circ} \mathrm{E}$ and 32.5 to $35.5^{\circ} \mathrm{N}$ ) has been carried out using the state-of-art remote sensing analyses from multi-satellite and ground-based observations, coupled with a radiative transfer model. The results of this study can be summarized as follows:

1. The seasonal mean MODIS-AODs (2010-2012) are in the ranges of $0.24-0.25,0.20-0.23,0.17-0.19$ and $0.17-0.18$ in spring, summer, autumn, and winter, respectively.

2. The CALIOP-derived AODs of dominant aerosol types are $0.22 \pm 0.02,0.11 \pm 0.04,0.10 \pm 0.04$ and $0.06 \pm 0.01$ for polluted dust, polluted continental, dust and marine aerosol, respectively.

3. Direct measurement of the effect of aerosol loading (MODIS) on atmospheric temperature profiles (AIRS) shows a warming of $\sim 1.7 \pm 0.8 \mathrm{~K} \mathrm{day}^{-1}$ in the aerosol layer, which is likely due to direct absorption of incoming shortwave solar radiation.

4. RTM-derived results show maximal atmospheric heating for polluted dust $\left(0.1-0.9 \mathrm{~K} \mathrm{day}^{-1}\right)$ followed by polluted continental $\left(0.1-0.5 \mathrm{~K} \mathrm{day}^{-1}\right)$ in lower troposphere $(<3.0 \mathrm{~km})$. 
5. In summer 2010, the daytime average atmospheric forcing is found to be $+16.7 \pm 7.9,+9.4 \pm 4.9$ and $+6.4 \pm 4.5 \mathrm{Wm}^{-2}$ for polluted dust, dust and polluted continental aerosols, respectively.

The findings from this study lead to a well-approximated assessment of the effects of absorbing aerosols, and the coupling of pollution and natural dust on the radiation budget in the eastern Mediterranean. These results enable to formulate mitigation and adaptation scenarios based on reliable observations and scientific understanding.

\section{The Supplement related to this article is available online at doi:10.5194/acp-14-7213-2014-supplement.}

Acknowledgements. This research was funded by a grant from the German Israeli Science Foundation (GIF), Project no. 113626.8/2011. The various satellite data sets were obtained from the NASA Langley Research Centre Atmospheric Science Data Center. The efforts of PIs of various AERONET sites used in this study are highly appreciated. Authors would like to thanks the reviewers for his valuable comments and suggestions.

Edited by: M. Kanakidou

\section{References}

Abdou, W. A., Diner, D. J., Martonchik, J. V., Bruegge, C. J., Kahn, R. A., Gaitley, B. J., Crean, K. A., Remer, L. A., and Holben, B.: Comparison of coincident Multiangle Imaging Spectroradiometer and Moderate Resolution Imaging Spectroradiometer aerosol optical depths over land and ocean scenes containing Aerosol Robotic Network sites, J. Geophys. Res.-Atmos., 110, D10S07, doi:10.1029/2004JD004693, 2005.

Ackerman, A. S., Toon, O. B., Stevens, D. E., Heymsfield, A. J., Ramanathan, V., and Welton, E. J.: Reduction of tropical cloudiness by soot, Science, 288, 1042-1047, 2000.

Aumann, H. H., Chahine, M. T., Gautier, C., Goldberg, M. D., Kalnay, E., McMillin, L. M., Revercomb, H., Rosenkranz, P. W., Smith, W. L., Staelin, D. H., Strow, L. L., and Susskind, J.: AIRS/AMSU/HSB on the Aqua mission: Design, science objectives, data products, and processing systems, IEEE T. Geosci. Remote., 41, 253-264, 2003.

Basart, S., Pérez, C., Cuevas, E., Baldasano, J. M., and Gobbi, G. P.: Aerosol characterization in Northern Africa, Northeastern Atlantic, Mediterranean Basin and Middle East from direct-sun AERONET observations, Atmos. Chem. Phys., 9, 8265-8282, doi:10.5194/acp-9-8265-2009, 2009.

Bergamo, A., Tafuro, A. M., Kinne, S., De Tomasi, F., and Perrone, M. R.: Monthly-averaged anthropogenic aerosol direct radiative forcing over the Mediterranean based on AERONET aerosol properties, Atmos. Chem. Phys., 8, 6995-7014, doi:10.5194/acp8-6995-2008, 2008.

Boucher, O., Schwartz, S. E., Ackerman, T. P. Anderson, T. L. Bergstrom, B. Bonnel, B., Chylek, P., Dahlback, A., Fouquart, Y., Fu, Q., Halthore, R. N., Haywood, J. M. Iversen, T., Kato,
S., Kinne, S., Kirkevag, A., Knapp, K. R., Lacis, A., Laszlo, I., Mishchenko, M. I., Nemesure, S., Ramaswamy, V., Roberts, D. L., Russell, P., Schlesinger, M. E., Stephens, G. L., Wagener, R., Wang, M., Wong, J., and Yang, F.: Intercomparison of models representing direct shortwave radiative forcing by sulfate aerosols, J. Geophys. Res.-Atmos., 103, 16979-16998, 1998.

Burton, S. P., Ferrare, R. A., Vaughan, M. A., Omar, A. H., Rogers, R. R., Hostetler, C. A., and Hair, J. W.: Aerosol classification from airborne HSRL and comparisons with the CALIPSO vertical feature mask, Atmos. Meas. Tech., 6, 13971412, doi:10.5194/amt-6-1397-2013, 2013.

Davidi, A., Koren, I., and Remer, L.: Direct measurements of the effect of biomass burning over the Amazon on the atmospheric temperature profile, Atmos. Chem. Phys., 9, 8211-8221, doi:10.5194/acp-9-8211-2009, 2009.

Davidi, A., Kostinski, A. B., Koren, I., and Lehahn, Y.: Observational bounds on atmospheric heating by aerosol absorption: Radiative signature of transatlantic dust, Geophys. Res. Lett., 39, L04803, doi:10.1029/2011GL050358, 2012.

Derimian, Y., Karnieli, A., Kaufman, Y. J., Andreae, M. O., Andreae, T. W., Dubovik, O., Maenhaut, W., Koren, I., and Holben, B. N.: Dust and pollution aerosols over the Negev desert, Israel: Properties, transport, and radiative effect, J. Geophys. Res. Atmos., 111, D05205, doi:10.1029/2005JD006549, 2006.

DeSouza-Machado, S. G., Strow, L. L., Hannon, S. E., and Motteler, H. E.: Infrared dust spectral signatures from AIRS, Geophys. Res. Lett., 33, L03801, doi:10.1029/2005GL024364, 2006.

Di Biagio, C., di Sarra, A., and Meloni, D.: Large atmospheric shortwave radiative forcing by Mediterranean aerosols derived from simultaneous ground-based and spaceborne observations and dependence on the aerosol type and single scattering albedo, J. Geophys. Res. Atmos., 115, D10209, doi:10.1029/2009JD012697, 2010.

Di Iorio, T., di Sarra, A., Sferlazzo, D. M., Cacciani, M., Meloni, D., Monteleone, F., Fuà, D., and Fiocco, G.: Seasonal evolution of the tropospheric aerosol vertical profile in the central Mediterranean and role of desert dust, J. Geophys. Res. Atmos., 114, D02201, doi:10.1029/2008JD010593, 2009.

Di Sarra, A., Pace, G., Meloni, D., De Silvestri, L., Piacentino, S., and Monteleone, F.: Surface shortwave radiative forcing of different aerosol types in the Mediterranean, Geophys. Res. Lett., 35, L02714, doi:10.1029/2007GL032395, 2008.

Diao, M., L. Jumbam, J., Sheffield, E. F. Wood, and Zondlo, M. A.: Validation of AIRS/AMSU-A water vapor and temperature data with in situ aircraft observations from the surface to UT/LS from $87^{\circ} \mathrm{N}-67^{\circ} \mathrm{S}$, J. Geophys. Res.-Atmos., 118, 6816-6836, doi:10.1002/jgrd.50483, 2013.

Diner, D. J., Beckert, J. C., Reilly, T. H., Bruegge, C. J., Conel, J. E., Kahn, R. A., Martonchik, J. V., Ackerman, T. P., Davies, R., Gerstl, S. A. W., Gordon, H. R., Muller, J.-P., Myneni, R., Sellers, P. J., Pinty, B., and Verstraete, M. M.: Multiangle Imaging Spectroradiometer (MISR) Instrument Description and Experiment Overview, IEEE T. Geosci. Remote., 36, 1072-1087, doi:10.1109/36.700992, 1998.

Dubovik, O., Smirnov, A., Holben, B. N., King, M. D., Kaufman, Y .J., Eck, T. F., and Slutsker, I.: Accuracy assessments of aerosol optical properties retrieved from AERONET sun and skyradiance measurements, J. Geophys. Res. Atmos., 105, 97919806, 2000. 
Dubovik, O., Holben, B. N., Eck, T. F., Smirnov, A., Kaufman, Y. J., King, M. D., Tanre, D., and Slutsker, I.: Variability of absorption and optical properties of key aerosol types observed in worldwide locations, J. Atmos. Sci., 59, 590-608, 2002.

Eck, T. F., Holben, B. N., Reid, J. S., Dubovik, O., Smirnov, A., O'Neill, N. T., Slutsker, I., and Kinne, S.: Wavelength dependence of the optical depth of biomass burning, urban, and desert dust aerosols, J. Geophys. Res.-Atmos., 104, 3133331349, doi:10.1029/1999JD900923, 1999.

Eck, T. F., Holben, B. N., Sinyuk, A., Pinker, R. T., Goloub, P., Chen, H., Chatenet, B., Li, Z., Singh, R. P., Tripathi, S. N., Reid, J. S., Giles, D. M., Dubovik, O., O’Neill, N. T., Smirnov, A., Wang, P., and Xia, X.: Climatological aspects of the optical properties of fine/coarse mode aerosol mixtures, J. Geophys. Res.Atmos., 115, D19205, doi:10.1029/2010JD014002, 2010.

Eck, T. F., Holben, B. N., Reid, J. S., Mukelabai, M. M., Piketh, S. J., Torres, O., Jethva, H. T., Hyer, E. J., Ward, D. E., Dubovik, O., Sinyuk, A., Schafer, J. S., Giles, D. M., Sorokin, M., Smirnov, A., and Slutsker, I.: A seasonal trend of single scattering albedo in southern African biomass-burning particles: Implications for satellite products and estimates of emissions for the world's largest biomass-burning source, J. Geophys. Res. Atmos., 118, 6414-6432, doi:10.1002/jgrd.50500, 2013.

Erel, Y., Dayan, U., Rabi, R., Rudich, Y., and Stein, M.: Tracing Trans-Boundary Transport of Pollutants by Mineral Dust, Environ. Sci. Technol., 40, 2996-3005, 2006.

Forster, P., Ramaswamy, V., Artaxo, P., Berntsen, T., Betts, R., Fahey, D. W., Haywood, J., Lean, J., Lowe, D. C., Myhre, G., Nganga, J., Prinn, R., Raga, G., Schulz, M., and Van Dorland, R.: Changes in Atmospheric Constituents and in Radiative Forcing, in: Climate Change 2007: The Physical Science Basis, Contribution of Working Group I to the Fourth Assessment Report of the Intergovernmental Panel on Climate Change, edited by: Solomon, S., Qin, D., Manning, M., Chen, Z., Marquis, M., Averyt, K. B., Tignor, M., and Miller, H. L., Cambridge University Press, Cambridge, United Kingdom and New York, NY, USA, 2007.

Gerasopoulos, E., Kouvarakis, G., Babasakalis, P., Vrekoussis, M., Putaud, J.-P., and Mihalopoulos, N.: Origin and variability of particulate matter $\left(\mathrm{PM}_{10}\right)$ mass concentrations over the eastern Mediterranean, Atmos. Environ., 40, 4679-4690, doi:10.1016/j.atmosenv.2006.04.020, 2006.

Giles, D. M., Holben, B. N., Eck, T. F., Sinyuk, A., Smirnov, A., Slutsker, I., Dickerson, R. R., Thompson, A. M., and Schafer, J. S.: An analysis of AERONET aerosol absorption properties and classifications representative of aerosol source regions, J. Geophys. Res.-Atmos., 117, D17203, doi:10.1029/2012JD018127, 2012.

Hess, M., Koepke, P., and Schult, I.: Optical Properties of Aerosols and Clouds: The Software Package OPAC, B. Am. Meteorol. Soc., 79, 831-44, 1998.

Holben, B. N., Eck, T. F., Slutsker, I., Tanre, D., Buis, J. P., Setzer, A., Vermote, E., Reagan, J. A., Kaufman, Y. J., Nakajima, T., Lavenu, F., Jankowiak, I., and Smirnov, A.: AERONET-A federated instrument network and data archive for aerosol characterization, Remote Sens. Environ., 66, 1-16, doi:10.1016/S00344257(98)00031-5, 1998.

Holben, B. N., Tanre, D., Smirnov, A., Eck, T. F., Slutsker, I., Abuhassan, N. Newcomb, W. W., Schafer, J. S., Chatenet, B.,
Lavenu, F., Kaufman, Y. J., Castle J. V., Setzer, A., Markham, B., Clark, D., Frouin, R., Halthore, R., Karneli, A., O’Neill, N. T., Pietras, C., Pinker, R. T., Voss, K., and Zibordi, G.: An emerging ground-based aerosol climatology: Aerosol optical depth from AERONET, J. Geophys. Res.-Atmos., 106, 12067-12097, doi:10.1029/2001JD900014, 2001.

Huang, J., Fu, Q., Su, J., Tang, Q., Minnis, P., Hu, Y., Yi, Y., and Zhao, Q.: Taklimakan dust aerosol radiative heating derived from CALIPSO observations using the Fu-Liou radiation model with CERES constraints, Atmos. Chem. Phys., 9, 4011-4021, doi:10.5194/acp-9-4011-2009, 2009.

Jones, T. A. and Christopher, S. A.: MODIS derived fine mode fraction characteristics of marine, dust, and anthropogenic aerosols over the ocean, constrained by GOCART, MOPITT, and TOMS, J. Geophys. Res.-Atmos., 112, D22204, doi:10.1029/2007JD008974, 2007.

Jones, T. A. and Christopher, S. A.: A reanalysis of MODIS fine mode fraction over ocean using OMI and daily GOCART simulations, Atmos. Chem. Phys., 11, 5805-5817, doi:10.5194/acp11-5805-2011, 2011.

Kahn, R. A., Garay, M. J., Nelson, D. L., Yau, K. K., Bull, M. A., Gaitley, B. J., Martonchik, J. V., and Levy, R. C.: Satellitederived aerosol optical depth over dark water from MISR and MODIS: Comparisons with AERONET and implications for climatological studies. J. Geophys. Res.-Atmos., 112, D18205, doi:10.1029/2006JD008175, 2007.

Kahn, R., Gaitley, B., Martonchik, J., Diner, D., Crean, K., and Holben, B.: MISR global aerosol optical depth validation based on two years of coincident AERONET observations. J. Geophys. Res.-Atmos., 110, D10S04. doi:10.1029/2004JD004706, 2005.

Kallos, G., Astitha, M., Katsafados, P., and Spyrou, C.: Long-range transport of anthropogenically and naturally produced particulate matter in the Mediterranean and North Atlantic: Current state of knowledge, J. Appl. Meteorol. Clim., 46, 1230-1251, doi:10.1175/JAM2530.1, 2007.

Kaufman, Y. J. and Koren, I.: Smoke and pollution aerosol effect on cloud cover, Science, 313, 355-658, 2006.

Kaufman, Y. J., Tanré, D., Dubovik, O., Karnieli, A., and Remer, L. A.: Absorption of sunlight by dust as inferred from satellite and ground-based remote sensing, Geophys. Res. Lett., 28, 1479-1482, 2001.

Kaufman, Y. J., Boucher, O., Tanré, D., Chin, M., Remer, L. A., and Takemura, T.: Aerosol anthropogenic component estimated from satellite data, Geophys. Res. Lett., 32, L17804, doi:10.1029/2005GL023125, 2005.

Kazadzis, S., Kouremeti, N., Bais, A., Kazantzidis, A., and Meleti, C.: Aerosol forcing efficiency in the UVA region from spectral solar irradiance measurements at an urban environment, Ann. Geophys., 27, 2515-2522, doi:10.5194/angeo-27-25152009, 2009.

Khain, A. P.: Notes on state-of-the-art investigations of aerosol effects on precipitation: a critical review, Environ. Res. Lett., 4, 015004, doi:10.1088/1748-9326/4/1/015004, 2009.

Koren, I., Martins, J. V., Remer, L. A., and Afargan, H.: Smoke Invigoration Versus Inhibition of Clouds over the Amazon, Science, 321, 946-949, doi:10.1126/science.1159185, 2008.

Leibensperger, E. M., Mickley, L. J., Jacob, D. J., Chen, W.-T., Seinfeld, J. H., Nenes, A., Adams, P. J., Streets, D. G., Kumar, N., and Rind, D.: Climatic effects of 1950-2050 changes in US anthro- 
pogenic aerosols - Part 1: Aerosol trends and radiative forcing, Atmos. Chem. Phys., 12, 3333-3348, doi:10.5194/acp-12-33332012, 2012.

Lelieveld, J., Berresheim, H., Borrmann, S., Crutzen, P. J., Dentener, F. J., Fischer, H., Feichter, J., Flatau, P. J., Heland, J., Holzinger, R., Korrmann, R., Lawrence, M. G., Levin, Z., Markowicz, K. M., Mihalopoulos, N., Minikin, A., Ramanathan, V., De Reus, M., Roelofs, G. J., Scheeren, H. A., Sciare, J., Schlager, H., Schultz, M., Siegmund, P., Steil, B., Stephanou, E. G., Stier, P., Traub, M., Warneke, C., Williams, J., and Ziereis, H.: Global air pollution crossroads over the Mediterranean, Science, 298, 794-799, doi:10.1126/science.1075457, 2002.

Levy, R. C., Remer, L. A., Mattoo, S., Vermote, E. F., and Kaufman, Y. J.: Second-generation operational algorithm: Retrieval of aerosol properties over land from inversion of Moderate Resolution Imaging Spectroradiometer spectral reflectance, J. Geophys. Res., 112, D13211, doi:10.1029/2006JD007811, 2007.

Li, Z., Niu, F., Fan, J., Liu, Y., Rosenfeld, D., and Ding, Y.: Longterm impacts of aerosols on the vertical development of clouds and precipitation, Nat. Geosci., 4, 888-894, 2011.

Ma, X., Bartlett, K., Harmon, K., and Yu, F.: Comparison of AOD between CALIPSO and MODIS: significant differences over major dust and biomass burning regions, Atmos. Meas. Tech., 6, 2391-2401, doi:10.5194/amt-6-2391-2013, 2013.

Maddy, E. S., DeSouza-Machado, S. G., Nalli, N. R., Barnet, C. D., Strow, L. L., Wolf, W. W., Xie, H., Gambacorta, A., King, T. S., Joseph, E., Morris, V., Hannon, S. E., and Schou, P.: On the effect of dust aerosols on AIRS and IASI operational level 2 products, Geophys. Res. Lett., 39, L10809, doi:10.1029/2012GL052070, 2012.

Mallet, M., Dubovik, O., Nabat, P., Dulac, F., Kahn, R., Sciare, J., Paronis, D., and Léon, J. F.: Absorption properties of Mediterranean aerosols obtained from multi-year ground-based remote sensing observations, Atmos. Chem. Phys., 13, 9195-9210, doi:10.5194/acp-13-9195-2013, 2013.

Marconi, M., Sferlazzo, D. M., Becagli, S., Bommarito, C., Calzolai, G., Chiari, M., di Sarra, A., Ghedini, C., Gómez-Amo, J. L., Lucarelli, F., Meloni, D., Monteleone, F., Nava, S., Pace, G., Piacentino, S., Rugi, F., Severi, M., Traversi, R., and Udisti, R.: Saharan dust aerosol over the central Mediterranean Sea: $\mathrm{PM}_{10}$ chemical composition and concentration versus optical columnar measurements, Atmos. Chem. Phys., 14, 2039-2054, doi:10.5194/acp-14-2039-2014, 2014.

Marey, H. S., Gille, J. C., El-Askary, H. M., Shalaby, E. A., and El-Raey, M. E.: Aerosol climatology over Nile Delta based on MODIS, MISR and OMI satellite data, Atmos. Chem. Phys., 11, 10637-10648, doi:10.5194/acp-11-10637-2011, 2011.

Markowicz, K. M., Flatau, P. J., Ramana, M. V., Crutzen, P. J., and Ramanathan, V.: Absorbing mediterranean aerosols lead to a large reduction in the solar radiation at the surface, Geophys. Res. Lett., 29, 1968, doi:10.1029/2002GL015767, 2002.

McClatchey, R. A., Fenn, R. W., Selby, J. E. A., Volz, F. E., and Garing, J. S.: Optical properties of the atmosphere, 3rd Edn., AFCRL Environ. Res. Papers No. 411, 108 pp., 1972.

McComiskey, A., Schwartz, S. E., Schmid, B., Guan, H., Lewis, E. R., Ricchiazzi, P., and Ogren, J. A.: Direct aerosol forcing: Calculation from observables and sensitivities to inputs, J. Geophys. Res.-Atmos., 113, D09202, doi:10.1029/2007JD009170, 2008.
Mélin, F. and Zibordi, G.: Aerosol variability in the Po Valley analyzed from automated optical measurements, Geophys. Res. Lett., 32, L03810, doi:10.1029/2004GL021787, 2005.

Meloni, D., di Sarra, A., Deluisi, J., Di Iorio, T., Fiocco, G., Junkermann, W., and Pace, G.: Tropospheric aerosols in the Mediterranean: 2. Radiative effects through model simulations and measurements, J. Geophys. Res.-Atmos., 108, 4317, doi:10.1029/2002JD002807, 2003.

Mielonen, T., Arola, A., Komppula, M., Kukkonen, J., Koskinen, J., de Leeuw, G., and Lehtinen, K. E. J.: Comparison of CALIOP level 2 aerosol subtypes to aerosol types derived from AERONET inversion data, Geophys. Res. Lett., 36, L18804, doi:10.1029/2009GL039609, 2009.

Moulin, C., Lambert, C. E., Dayan, U., Masson, T. M. V., Ramonet, M., Bousquet, P., Legrand, M., Balkanski, Y. J., Guelle, W., Marticorena, B., Bergametti, G., and Dulac, F.: Satellite climatology of African dust transport in the Mediterranean atmosphere, J. Geophys. Res.-Atmos., 103, 1313713144, doi:10.1029/98JD00171, 1998.

Nabat, P., Somot, S., Mallet, M., Chiapello, I., Morcrette, J. J., Solmon, F., Szopa, S., Dulac, F., Collins, W., Ghan, S., Horowitz, L. W., Lamarque, J. F., Lee, Y. H., Naik, V., Nagashima, T., Shindell, D., and Skeie, R.: A 4-D climatology (1979-2009) of the monthly tropospheric aerosol optical depth distribution over the Mediterranean region from a comparative evaluation and blending of remote sensing and model products, Atmos. Meas. Tech., 6, 1287-1314, doi:10.5194/amt-6-12872013, 2013.

Omar, A. H., Winker, M. D., Vaughan, M. A., Hu, Y., Trepte, C. R., Ferrare, R. A., Lee, K.-P., Hostetler, C. A., Kittaka, C., Rogers, R. R., Kuehn, R. E., and Liu, Z.: The CALIPSO automated aerosol classification and lidar ratio selection algorithm, J. Atmos. Ocean. Tech., 26, 1994-2014, 2009.

Oo, M. and Holz, R.: Improving the CALIOP aerosol optical depth using combined MODIS-CALIOP observations and CALIOP integrated attenuated total color ratio, J. Geophys. Res.-Atmos., 116, D14201, doi:10.1029/2010jd014894, 2011.

Pace, G., di Sarra, A., Meloni, D., Piacentino, S., and Chamard, P.: Aerosol optical properties at Lampedusa (Central Mediterranean). 1. Influence of transport and identification of different aerosol types, Atmos. Chem. Phys., 6, 697-713, doi:10.5194/acp-6-697-2006, 2006.

Papadimas, C. D., Hatzianastassiou, N., Matsoukas, C., Kanakidou, M., Mihalopoulos, N., and Vardavas, I.: The direct effect of aerosols on solar radiation over the broader Mediterranean basin, Atmos. Chem. Phys., 12, 7165-7185, doi:10.5194/acp-12-71652012, 2012.

Peña, O. and Pal, U.: Scattering of electromagnetic radiation by a multilayered sphere, Comput. Phys. Commun., 180, 2348-2354, 2009.

Pierangelo, C., Chédin, A., Heilliette, S., Jacquinet-Husson, N., and Armante, R.: Dust altitude and infrared optical depth from AIRS, Atmos. Chem. Phys., 4, 1813-1822, doi:10.5194/acp-41813-2004, 2004.

Ramanathan, V., Crutzen, P. J., Lelieveld, J., Mitra, A. P., Althausen, D., Anderson, J., Andreae, M. O., Cantrell, W., Cass, G. R., Chung, C. E., Clarke, A. D., Coakley, J. A., Collins, W. D., Conant, W. C., Dulac, F., Heintzenberg, J., Heymsfield, A. J., Holben, B., Howell, S., Hudson, J., Jayaraman, A., Kiehl, J. T., 
Krishnamurti, T. N., Lubin, D., McFarquhar, G., Novakov, T., Ogren, J. A., Podgorny, I. A., Prather, K., Priestley, K., Prospero, J. M., Quinn, P. K., Rajeev, K., Rasch, P., Rupert, S., Sadourny, R., Satheesh, S. K., Shaw, G. E., Sheridan, P., and Valero, F. P. J.: Indian Ocean Experiment: An integrated analysis of the climate forcing and effects of the great Indo-Asian haze, J. Geophys. Res.-Atmos., 106, 28371-28398, 2001.

Ramanathan, V., Chung, C., Kim, D., Bettge, T., Buja, L., Kiehl, J. T., Washington, W. M., Fu, Q., Sikka, D. R., and Wild, M.: Atmospheric brown clouds: Impacts on South Asian climate and hydrological cycle, P. Natl. Acad. Sci., USA, 102, 5326-5333, 2005.

Reid, J. S., Kinney, J. E., Westphal, D. L., Holben, B. N., Welton, E. J., Tsay, S., Eleuterio, D. P., Campbell, J. R., Christopher, S. A., Colarco, P. R., Jonsson, H. H., Livingston, J. M., Maring, H. B., Meier, M. L., Pilewskie, P., Prospero, J. M., Reid, E. A., Remer, L. A., Russell, P. B., Savoie, D. L., Smirnov, A., and Tanré, D. : Analysis of measurements of Saharan dust by airborne and ground-based remote sensing methods during the Puerto Rico Dust Experiment (PRIDE), J. Geophys. Res.-Atmos., 108, 8586, doi:10.1029/2002JD002493, 2003.

Remer, L. A., Kleidman, R. G., Levy, R. C., Kaufman, Y. J., Tanre, D., Mattoo, S., Martins, J. V., Ichoku, C., Koren, I., Yu, H., and Holben, B. N.: Global aerosol climatology from the MODIS satellite sensors, J. Geophys. Res. Atmos., 113, D14S07, doi:10.1029/2007JD009661, 2008.

Ricchiazzi, P., Yang, S., Gautier, C., and Sowle, D.: SBDART: A research and teaching software tool for plane-parallel radiative transfer in the Earth's atmosphere, B. Am. Meteorol. Soc., 79, 2101-2114, 1998.

Rothman, L. S., Jacquemart, D., Barbe, A., Chris Benner, D., Birk, M., Brown, L. R., Carleer, M. R., Chackerian, C., Chance, K., Coudert, L. H., Dana, V., Devi, V. M., Flaud, J.-M., Gamache, R. R., Goldman, A., Hartmann, J.-M., Jucks, K. W., Maki, A. G., Mandin, J.-Y., Massie, S. T., Orphal, J., Perrin, A., Rinsland, C. P., Smith, M. A. H., Tennyson, J., Tolchenov, R. N., Toth, R. A., Vander Auwera, J., Varanasi, P., and Wagner, G.: The HITRAN 2004 molecular spectroscopic database, J. Quant. Spectrosc. Ra., 96, 139-204, 2005.

Russell, P. B., Bergstrom, R. W., Shinozuka, Y., Clarke, A. D., DeCarlo, P. F., Jimenez, J. L., Livingston, J. M., Redemann, J., Dubovik, O., and Strawa, A.: Absorption Angstrom Exponent in AERONET and related data as an indicator of aerosol composition, Atmos. Chem. Phys., 10, 1155-1169, doi:10.5194/acp-101155-2010, 2010.

Santese, M., Perrone, M. R., Zakey, A. S., De Tomasi, F., and Giorgi, F.: Modeling of Saharan dust outbreaks over the Mediterranean by RegCM3: case studies, Atmos. Chem. Phys., 10, 133156, doi:10.5194/acp-10-133-2010, 2010.

Seiki, T. and Nakajima, T.: Aerosol Effects of the Condensation Process on a Convective Cloud Simulation, J. Atmos. Sci., 71, 833-853, doi:10.1175/JAS-D-12-0195.1, 2014.

Shi, Y., Zhang, J., Reid, J. S., Hyer, E. J., Eck, T. F., Holben, B. N., and Kahn, R. A.: A critical examination of spatial biases between MODIS and MISR aerosol products - application for potential AERONET deployment, Atmos. Meas. Tech., 4, 2823 2836, doi:10.5194/amt-4-2823-2011, 2011.

Sinyuk, A., Holben, B. N., Smirnov, A., Eck, T. F., Slutsker, I., Schafer, J. S., Giles, D. M., and Sorokin, M.: Assessment of error in aerosol optical depth measured by AERONET due to aerosol forward scattering, Geophys. Res. Lett., 39, L23806, doi:10.1029/2012GL053894, 2012.

Stamnes, K., Tsay, C., Wiscombe, W., and Jayaweera, K.: Numerically stable algorithm for discrete-ordinate-method radiative transfer in multiple scattering and emitting layered media, Appl. Optics, 27, 2502-2509, 1988.

Stevens, B. and Feingold, G.: Untangling aerosol effects on clouds and precipitation in a buffered system, Nature, 461, 607-613, 2009.

Tanré, D., Deroo, C., Duhaut, P., Herman, M., Morcrette, J. J., Perbos, J., and Deschamps, P. Y.: Description of a computer code to simulate the satellite signal in the solar spectrum: The $5 \mathrm{~S}$ code, Int. J. Remote Sens., 11, 659-668, 1990.

Tanré, D., Kaufman, Y. J., Holben, B. N., Chatenet, B., Karnieli, A., Lavenu, F., Blarel, L., Dubovik, O., Remer, L. A., and Smirnov, A.: Climatology of dust aerosol size distribution and optical properties derived from remotely sensed data in the solar spectrum, J. Geophys. Res.-Atmos., 106, 18205-18217, doi:10.1029/2000JD900663, 2001.

Vrekoussis, M., Liakakou, E., Kocak, M., Kubilay, N., Oikonomou, K., Sciare, J., and Mihalopoulos, N.: Seasonal variability of optical properties of aerosols in the Eastern Mediterranean, Atmos. Environ., 39, 7083-7094, 2005.

Wang, K.-Y.: Profiles of the atmospheric temperature response to the Saharan dust outbreaks derived from FORMOSAT3/COSMIC and OMI AI, Atmos. Res., 96, 110-121, doi:10.1016/j.atmosres.2009.11.017, 2010.

Winker, D. M., Pelon, J., and McCormick, M. P.: The CALIPSO mission: Space borne lidar for observation of aerosols and clouds, Proc. SPIE 4893, P. Soc. Photo-Opt. Ins., 1, 1-11, doi:10.1117/12.466539, 2003.

Winker, D. M., Tackett, J. L., Getzewich, B. J., Liu, Z., Vaughan, M. A., and Rogers, R. R.: The global 3-D distribution of tropospheric aerosols as characterized by CALIOP, Atmos. Chem. Phys., 13, 3345-3361, doi:10.5194/acp-13-33452013, 2013.

Wu, C. F. J.: Jackknife, bootstrap and other resampling methods in regression analysis, The Annals of Statistics, 14, 1261-1295, 1986.

Xiao, N., Shi, T., Calder, C. A., Munroe, D. K., Berrett, C., Wolfinbarger, S., and Li, D.: Spatial characteristics of the difference between MISR and MODIS aerosol optical depth retrievals over mainland Southeast Asia, Remote Sens. Environ., 113, 1-9, 2009.

Young, S. A. and Vaughan M. A.: The Retrieval of Profiles of Particulate Extinction from Cloud-Aerosol Lidar Infrared Pathfinder Satellite Observations (CALIPSO) Data: Algorithm Description, J. Atmos. Ocean. Tech., 26, 1105-1119, 2009.

Yu, H., Chin, M., Remer, L. A., Kleidman, R., Bellouin, N., Blan, H., and Diehl, T.: Variability of marine aerosol fine mode fraction estimates of anthropogenic aerosol component over cloudfree oceans from the Moderate Resolution Imaging Spectroradiometer (MODIS), J. Geophys. Res.-Atmos., 114, D10206, doi:10.1029/2008JD010648, 2009.

Zhang, L., Li, Q. B., Gu, Y., Liou, K. N., and Meland, B.: Dust vertical profile impact on global radiative forcing estimation using a coupled chemical-transport-radiative-transfer model, At- 
mos. Chem. Phys., 13, 7097-7114, doi:10.5194/acp-13-70972013, 2013.

Zhu, A., Ramanathan, V., Li, F., and Kim, D.: Dust plumes over the Pacific, Indian, and Atlantic oceans: Climatology and radiative impact, J. Geophys. Res.-Atmos., 112, D16208, doi:10.1029/2007JD008427, 2007. 